\title{
Halk Egemenliği ve Milli Egemenlik Teorileri Bağlamında Anayasacılık
}

\author{
Sabahattin Nal* ${ }^{\star}$, Furkan Çirkin ${ }^{* *}$
}

Öz

Bu makale, anayasacılığa egemenlik teorileri bağlamında yeni bir bakış açısı getirmeyi amaçlamaktadır. Anayasacılık, iktidarın sınırlandııımasını amaçlayan bir anlayışa dayanmaktadır. Ancak bu sınırlandırma devletin kendi içinde olmalıdır. Anayasacılık, dışarıdan bir müdahaleyle gelen sınırlandırmayı içermemektedir. Ilk olarak egemenliğin kaynağııı tanrıda gören teokratik egemenlik teorileri, hiçbir şekilde anayasacılıkla bağdaşmamaktadır. Asında egemenliğin kaynağı ne kadar geniş bir tabana yayılırsa egemenliği kullanan iktidar da o kadar çok sınırlandırıı. Bu bakımdan anayasacılık, geçmiş ve geleceği de kapsayan millet kavramına dayanan milli egemenlik teorisiyle sıkı bir ilişki içindedir. Milli egemenlik teorisine göre egemenliğin kaynağı ile onu kullanan iktidar birbirinden oldukça uzaklaşmakta ve anayasacılığın amacı olan iktidarın sınırlandırılması düşüncesi sağlıklı bir şekilde ortaya konulmaktadır. Günümüz demokrasilerinde anayasacılığın amacı, halkın çoğunluğunun iktidarını sınırlandırmak ve bireylerin haklarını çoğunluğa karşı güvenceye almak şeklinde okunabilir. Bu bakımdan somut bireylerin toplamından oluşan halka dayanan ve halkın çoğunluğunun genel iradesini en üstün sayan halk egemenliği teorisi, anayasacılık düşüncesiyle bağdaşmamaktadır.

Anahtar Kelimeler

Anayasacılık, Egemenlik teorileri, Milli egemenlik, Halk egemenliği, İktidarın sınırlandırılması

\section{Constitutionalism in the Context of Popular Sovereignty and National Sovereignty Theories}

\begin{abstract}
This article aims to bring a new perspective to constitutionalism in the context of sovereignty theories. Constitutionalism is based on an idea that aims to limit power; however, this limitation must be within the state as constitutionalism does not include external limitations. The theory of theocratic sovereignty, which posits that the source of sovereignty comes from God, is incompatible with constitutionalism. Indeed, the more widely the source of sovereignty is, the more restricted power is. In this respect, constitutionalism is closely related to the theory of national sovereignty, which is based on the concept of nation as including the past and future. According to the theory of national sovereignty, power is far from the source of sovereignty; thus, the idea of limiting power, which is the aim of constitutionalism, is realized in a healthy way. The aim of constitutionalism can be considered as limiting the power of the majority and securing the rights of individuals against it. In this respect, the theory of popular sovereignty, which is based on the people and regards the general will of the majority as supreme, is incompatible with the idea of constitutionalism.
\end{abstract}

\section{Keywords}

Constitutionalism, Sovereignty theories, National sovereignty, Popular sovereignty, Limitation of the power

* Sorumlu Yazar: Sabahattin Nal (Doç. Dr.), İstanbul Üniversitesi, Hukuk Fakültesi, Genel Kamu Hukuku Anabilim Dalı, İstanbul, Türkiye. E-Posta: senal79@hotmail.com ORCID: 0000-0002-2260-6746

** Furkan Çirkin (Arş. Gör.), Anadolu Üniversitesi, Hukuk Fakültesi, Anayasa Hukuku Anabilim Dalı, Eskişehir, Türkiye. E-Posta: cirkinfurkan@gmail.com ORCID: 0000-0003-3293-9525

Atıf: Nal S, Cirkin F, “Halk Egemenliği ve Milli Egemenlik Teorileri Bağlamında Anayasacılık” (2021) 79(2) İstanbul Hukuk Mecmuası 599. https://doi.org/10.26650/mecmua.2021.79.2.0099 


\section{Extended Summary}

State is defined as a community of people who have sovereignty within a specified territory; hence, elements of state are a community of people, a specified territory, and sovereignty. According to this definition, the existence of the state dates back to ancient times. The first states emerged a long time ago and had elements similar to those of modern state, such as a community of people, a specified territory, and sovereignty. However, these states did not have a constitution as we now understand it. Although most discussions are not in terms of territory and population but in terms of sovereignty, and considering that the concept of sovereignty emerged together with that of the modern state, some only view the state as the modern state. However, it is clear that some states in the past had sovereignty over a territory and a community of people, and this element of sovereignty was generally theocratic in origin. On the other hand, when its source shifted from theocracy to democracy, constitutionalism began to emerge.

Constitutionalism aims not only to regulate any state organization but also to create a state that limits the power and guarantees the freedom of individuals. We believe that theories of democratic sovereignty - and especially the theory of national sovereignty - also constitute the basis of constitutionalism; therefore, this study aims to bring a new perspective to constitutionalism in the context of sovereignty theories.

Although the elements of community and specified territory are basic material conditions of the state, the main factor that ensures its existence must be sovereignty because the power of the state over the territory and the community is related to it. Some theories have been proposed to explain sovereignty and its origin. States and their constitutions are shaped according to the theory of sovereignty that they are based on or adopt. Contemporary democratic states are based on popular sovereignty or national sovereignty.

A state uses its sovereignty equally with and independently from other states externally; nevertheless, it uses its sovereignty having absolute and permanent power against its own people internally. As a matter of fact, the word "sovereignty" is derived from the Latin superannus, meaning supreme; in short, it means supreme power.

There are different theories about the origin of sovereignty. First, theocratic theories had emerged and dominated for a long time. Later, with the development of democratic thought, the origin of sovereignty ceased to be God and began to be found in the people/nation. Nowadays, democratic theories have been adopted by most contemporary states. In the theory of popular sovereignty, it is claimed that sovereignty belongs to the people and that the people are the sum of the individuals living in that state. On the other hand, in the theory of national sovereignty, it is claimed that sovereignty belongs to the nation, which is an abstract personality 
separate from the sum of the individuals living in that state. Thus, the concept of nation includes not only the present but also the past and the future; in this respect, it is necessary to limit even the majority of the people within the understanding of the theory of national sovereignty.

Constitutionalism is the antithesis of arbitrary power, although it does not include external limitation. Therefore, limitation that undermines the sovereignty of the state is incompatible with constitutionalism. In our opinion, the wider the source of sovereignty, the more limited the power; for instance, as the idea of human rights is based on very wide framework, the ideas of human rights and international courts of human rights significantly limit power. However, it cannot be considered the source of sovereignty, and it undermines the sovereignty of the state. In contrast, constitutionalism claims that power must be limited within the state itself. In this respect, the theory of national sovereignty stands out as the state limits its own power within itself.

Aritcle 16 of the Declaration of the Rights of Man and of the Citizen states that "[a]ny society in which the guarantee of rights is not assured, nor the separation of powers determined, has no constitution." In this respect, the limitation of the power, which is the aim of constitutionalism, can only be achieved with the separation of powers, and the guarantee of rights is possible with a superior constitution and a functional constitutional court. Then, these features of constitutionalism are closely related to the theory of national sovereignty. Moreover, constitutionalism aims to limit the power of the majority and aims to protect individuals against it. As a result, by seeking to provide a limited power within the state, constitutionalism is closely related to the theory of national sovereignty, which bases the source of sovereignty on the widest framework within the state itself. 


\section{Halk Egemenliği ve Milli Egemenlik Teorileri Bağlamında Anayasacılık}

\section{Giriş}

Devletin temel unsurlarından biri egemenliktir. Hatta belirli bir toprak parçası ve insan topluluğu unsurları maddi temel şartlar olmakla beraber devletin var olmasını sağlayan asıl önemli unsur egemenliktir. Devletin toprak parçası ve insan topluluğu üzerindeki gücü egemenlikle ilişkilidir. Bir devlet egemenliğini dişta diğer devletlerle eşit ve diğer devletlerden bağımsız olarak içte ise kendi halkına karşı mutlak ve sürekli bir biçimde kullanır. Egemenliğin kaynağı konusunda farklı teoriler bulunmaktadır. İlk olarak teokratik egemenlik teorileri ortaya atılmıştır. Daha sonra ise demokratik düşüncenin gelişmesiyle birlikte egemenliğin kaynağı tanrıdan ziyade halka/millete dayandırılmaya başlanmıştır. Günümüz çağdaş demokratik devletleri, demokratik egemenlik teorileri olan halk egemenliğine ya da milli egemenliğe dayanmaktadır. $\mathrm{Bu}$ çalışma, anayasacılığa egemenlik teorileri bağlamında yeni bir bakış açısı getirmeyi amaçlamaktadır. Kanaatimizce egemenliğin kaynağı ne kadar geniş bir tabana yayılırsa egemenliği kullanan iktidar da o kadar sınırlı olacaktır.

Anayasacılık, sadece herhangi bir devlet teşkilatlanmasını düzenlemeyi değil aynı zamanda iktidarı sınırlandıran ve bireylerin özgürlüklerini güvence altına alan bir devlet teşkilatlanmasını amaçlamaktadır. Bu makalede ele alınan konu, liberal anayasacılık olarak da adlandırılan sınırlı iktidarı amaçlayan düşüncedir. Ancak bu anayasacılık düşüncesi, devletin egemenliğini zedeleyen ve dışarıdan bir müdahaleyle gelen sınırlandırmayı içermemektedir. Anayasacılık, devletin bir egemenliğe sahip olduğunu ve fakat egemenliği kullanan iktidarın devletin kendi içinde sınırlandııılması gerektiğini ortaya koymaktadır. Hatta anayasacılık, halkın çoğunluğun iradesini de sınırlandırmak istemektedir. Zira anayasacılık, kuvvetler ayrılığıyla dengelenmiş sınırlı bir iktidar ve çoğunluk karşısında azınlığın haklarını güvence altına alan bir sistem amaçlamaktadır. Bu bakımdan devletin iktidarını kendi isteğiyle sınırlandırması yani otolimitasyon bakımından milli egemenlik teorisi ön plana çıkmaktadır. Anayasacılığın amacı olan iktidarı sınırlandırmak ve bireylerin özgürlüklerini güvence altına almak fikri, milli egemenlik teorisiyle uyumludur ve kanaatimizce milli egemenlik teorisinden kaynaklanmaktadır.

\section{Devlet, Anayasacılık ve Devletin Bir Unsuru Olarak Egemenlik}

\section{A. Devlet ve Anayasacilı}

Devlet, belirli bir toprak parçası üzerinde egemenlik kurmuş olan belirli bir insan topluluğunun oluşturduğu varlıktır. ${ }^{1}$ Geleneksel genel devlet teorisi tanımından hareketle devletin temel unsurları toprak, insan ve egemenlik

\footnotetext{
Kemal Gözler, Devletin Genel Teorisi (10. Bası, Ekin Yayınevi 2020) 4.
} 
başlıkları altında incelenebilir. ${ }^{2} \mathrm{Bu}$ unsurları barındıran devletler, tarihsel olarak çok eskilere dayanmaktadır. Ancak yaygın görüşe göre ilk anayasa 1787 Amerika Birleşik Devletleri anayasasıdır. ${ }^{3}$ Tabi ki tarihteki birçok devletin kendince siyasi sistemi bulunmaktadır. Ancak bu sistemler, iktidarı sınırlandırmak amaciyla teşkilatlandırılmadığından anayasacılıkla ilişkilendirilemez. ${ }^{4}$

\section{Toprak, İnsan ve Egemenlik Unsurları}

Devlet olarak adlandırılan siyasi iktidar, sürekli kontrolü altında olan bir toprak parçasına sahip olmalıdır. ${ }^{5}$ Başka bir ifadeyle devlet, bir toprak parçasına sahip olmalıdır ve bu toprak parçasının sınırlarının belirli olması gerekmektedir. Dolayısıyla sınırları belirli bir toprak parçası üzerinde yerleşmemiş olan insanlar devleti meydana getiremezler. ${ }^{6}$ İkinci olarak devlet, kalıcı veya istikrarlı bir insan topluluğuna ( $a$ permanent or stable population) sahip olmalıdır. ${ }^{7}$ Tabi ki bu insanların sayıs1 on binlerle de yüz milyonlarla da ifade edilebilir. ${ }^{8}$ Önemli olan bir ülke üzerinde belirli sayıda insanın egemen olmasıdır. ${ }^{9}$ Yani bir devletten bahsedebilmemiz için sınırları belirli bir toprak parçası ve belirli bir insan topluluğu gerekmektedir. Bu insan topluluğu ise o toprak parçası üzerinde egemen olmalıdır. Toprak ve insan unsuru için devletin maddi unsurları diyebiliriz. ${ }^{10}$ Ancak devletin var olabilmesi için bu iki unsur yeterli değildir. Ayrıca bunlara ek olarak egemenlik unsuru da gereklidir. ${ }^{11}$ Hatta devletin temel unsurlarından en önemlisi ve en ayırt edicisi, egemenliktir. Zira devleti, bütün diğer insan topluluklarından ayıran en önemli özellik, egemenliktir. ${ }^{12}$

\footnotetext{
Bob Jessop, 'The State: Past, Present, Future' (2016) 7 Journal of Ritsumeikan Social Sciences and Humanities 73, 74 $<$ http://www.ritsumei.ac.jp/acd/re/k-rsc/hss/book/pdf/vol07_08.pdf> Erişim Tarihi 20.12.2020.

İbrahim Ö. Kaboğlu, Anayasa Hukuku Dersleri: Genel Esaslar (15. Bası, Legal Yayınevi 2020) 2.

4 Giovanni Sartori, 'Constitutionalism: A Preliminy Discussion' (1962) 56 (4) The American Political Science Review 853, 860; "Sınırlı devlet fikri/anayasacılık, keyfi kararlara dayanan yönetimin karşıtı olarak kendisini belli eder. Anayasacılık, keyfi yönetimin antitezidir." Adil Şahin, 'Siyasal Düşünceler Tarihinde 'Sınırlı Devlet' Fikrinin Kadimliği ya da Genel Kamu Hukuku Bağlamında İnsan, Özgürlük ve Devlet İktidarı Algısındaki Evrilme’ (2011) 15 (3) Gazi Üniversitesi Hukuk Fakültesi Dergisi 311, 311; "Bazı yazarlar anayasacılı̆̆ın köklerini çok daha eski tarihlere götürmektedir. Bu çerçevede anayasa teriminin Aristoteles'in politeia kavramından türediği söylenmektedir.” Kaboğlu (n 3) 7; Mete Tunçay, Aristotales'in Politika kitabında politeia kavramını anayasa olarak çevirmiş ve kullanmıştır. Bkz. Aristotales, Politika (Mete Tunçay çev, 22. Bası, Remzi Kitabevi 2020).

Selçuk Özçelik, Anayasa Hukuku 1: Umumi Esaslar (Beta Yayınevi 1984) 19; Gözler, Devlet Teorisi (n 1) 4; Jessop (n 2 ) 74.

6 “Göçebe kavimler devlet kuramamışlardır." Özçelik, (n 5) 20.

Jessop, (n 2) 74.

8 “İnsanlar olmaksızın bir devletin kurulması mümkün değildir. Ancak insan topluluğunun büyüklüğunün bir önemi yoktur. Bir tarafta on-onbeş bin nüfuslu Andorra, Saint-Marin, Kiribatu, Nauru Tuvalu gibi küçük devletler, diğer tarafta nüfusu yüz milyonlarla ifade edilen Çin, Hindistan, Amerika Birleşik Devletleri, Rusya gibi devletler de vardır.” Kemal Gözler, Anayasa Hukukuna Giriş, (29. Bası, Ekin Yayınevi 2020), 34.

9 ibid.

10 "Devletin meydana gelmesini hazırlayıcı mahiyetteki iki maddi unsur insan ve toprak unsurudur." Özçelik (n 5) 31.

11 ibid, 57.

12 Murat Sarıca, 100 Soruda Siyasi Düşünce Tarihi (Milenyum Yayınları 2017) 95.
} 


\section{Devleti 'Devlet' Yapan En Önemli Unsur: Egemenlik}

Yukarıda da belirtildiği gibi belirli bir toprak parçası ve belirli bir insan topluluğu devleti oluşturmaya yetmemektedir. Burada kilit nokta olarak karşımıza egemenlik çıkmaktadır. Bir insan topluluğu belirli bir toprak parçası üzerinde egemen olamıyorsa orada bir devletin varlığından söz edemeyiz. ${ }^{13}$ Dolayısıyla devletin temel üç unsurundan biri hatta devleti devlet yapan en önemli unsur egemenliktir. ${ }^{14}$ Örneğin İbni Haldun'a göre devlet, bir toplumun diğer bir toplum üzerinde egemenlik kurmasıyla ortaya çıkmaktadır. ${ }^{15}$ Zaten tarihsel süreçte de ilk devletlerin ortaya çıkış anı ile egemenliğin belirgin hâl alması aynı zaman dilimine denk gelmektedir. Devlet, ya göçebe toplulukların çiftçi topluluklar üzerinde egemenlik kurmasıyla artı aktarımı sömüren uygarlık olarak ya da büyük sulama tarımına geçişle birlikte merkezi bir egemenliğin ortaya çıkmasıyla hidrolik uygarlık (hydraulic civilization) olarak kurulmaktadır. ${ }^{16}$ Sonuç olarak devletin ortaya çıkışı, egemenlikle olmaktadır. ${ }^{17}$

\section{Anayasacılığın Amacı: Devlet İktidarının Sınırlandırılması}

Anayasacılık, keyfi yönetimin antitezi olarak sınırlı iktidarın sağlanması ve temel hak ve hürriyetlerin güvence altına alınması amacıyla hiyerarşik olarak en

13 Gözler, Anayasa Hukuku (n 8) 34; "Diğer yandan mademki egemenlik devletin kurucu ve olmazsa olmaz şartıdır; öyleyse devlet ancak egemenliğini koruduğu sürece hukuken vardır. Bu bağlamda, eğer devlet, zorlayıcıllı̆̆ını kaybetmişse veya tekel güç olmaktan çıkmışsa, sözünü geçirebilme gereksinimleri baş göstermişse artık devletin varlığından söz edilemeyecektir. Aynı şekilde egemenliğin kaybı ya da egemenliğin başka bir devlete ya da uluslararası kuruluş ya da oluşuma bütünüyle devri devletin yine hukuken varlığını yitirmesiyle sonuçlanır." Ömer Anayurt, Anayasa Hukuku Genel Kısım: Temel İlkeler, Kavram ve Kurumlar, (3. Bası, Seçkin Yayınevi 2020) 243.

14 "Geniş anlamıyla devlet yönetim aygitından, ulustan ve ülkeden oluşur. Ancak devletin her şeyden önce bir yönetim aygitı olduğu gerçeği unutulmamalıdır. Ulus da ülke de eninde sonunda devletin buyurma yetkisini kullanabileceği alanı sınırlayan öğelerdir. Görüldüğü gibi önemli olan bu buyurma yetkisidir. Buna egemenlik adı verilir." Cem Eroğul, Anatüzeye Giriş: “Anayasa Hukuku”na Giriş (7. Bası, İmaj Yayıncılık 2004) 6; "Devletin temel unsuru olan egemenliği, kavramsal olarak modern anlamda kullanan ilk düşünür Bodin'dir. Bodin'den daha sonra da egemenlik kavramını tanımlamaya yönelik birçok düşünce ortaya atılmıştır." Abdurrahman Saygılı, 'Jean Bodin'in Egemenlik Anlayışı Çerçevesinde Kralın İki Bedeni Kuramına Kısa Bir Bakış’ (2014) 63 (1) Ankara Üniversitesi Hukuk Fakültesi Dergisi 185, 185.

15 İbni Haldun, Mukaddime Cilt I (Turan Dursun çev, Onur Yayınları 1977) 142; Aynı şekilde Oppenheimer da insan topluluklarının birbiri üzerinde egemenlik kurmalarıyla devletin ortaya çıktığını ileri sürmektedir. Oppenheimer'a göre devlet; zafer kazanmış bir insan grubunun yendikleri üzerindeki egemenliğini bir düzene bağlamak ve kendini içten gelecek ayaklanmalarla dıştan gelecek saldırılara karşı güvenceye almak amacıyla yendiği gruba zorla kabul ettirdiği bir toplumsal kurumdur. Franz Oppenheimer, Devlet (Alaeddin Şenel, Yavuz Sabuncu çevr, Phoneix Yayınevi 2005) 38; Albert Jay Nock da devletin kökenini fetih ve el koyma yani zapt ve müsadere olarak açıklamaktadır. Nock'a göre ilk yağmacı insan grubunun bir araya gelmesiyle devlet ortaya çıkmıştır. Albert Jay Nock, 'Kriminal Bir Örgüt Olarak Devlet' Mustafa Erdoğan (çev) (2021) <https://www.sosyalbilimler.org/wp-content/uploads/2021/02/Albert-Jay-Nock-Kriminal-Bir-OrgutOlarak-Devlet.pdf> Erişim Tarihi 12.02.2021.

16 Gözler, Devlet Teorisi (n 1) 41; Alaeddin Şenel, Siyasal Düşünceler Tarihi: Tarihöncesinde İlkçağda Ortaçağda ve Yeniçağda Toplum ve Siyasal Düşünüş (7. Bası, Bilim ve Sanat Yayınları 2019) 41 vd.; Karl W. Butzer, Early Hydraulic Civilization in Egypt: A Study in Cultural Ecology (Chicago Press 1976) 19 vd < oi.uchicago.edu> Erişim Tarihi 01.01.2021.

17 Bununla birlikte modern anlamda egemenlik kavramını ilk kez kullanan Jean Bodin, modern devletle egemenliği özdeşleştirmektedir. İçte feodal senyörlere ve dışta da papalığa karşı gücünü ispat eden krallık, mutlak monarşisini hukuki anlamda egemenlik kavramıyla bir temele oturtmaktadır. Münci Kapani, Politika Bilimine Giriş, (BB101 Yayınları 2019$) 65$. 
üstün olan, zor değiştirilen, katı bir anayasanın yapılmasını isteyen akımdır. ${ }^{18}$ Fakat buradaki en önemli husus, anayasacılığın güçlü bir ulus devlet anlayışıyla sıkı bir bağ içinde oluşudur. Öyle ki anayasacılık, bir ulus devlet içinde kendi devlet iktidarını sınırlandırmayı ve yine kendi iç hukukunda üstün bir anayasaya dayanan temel hak ve hürriyetleri koruma altına almayı amaçlamaktadır. Bu sınırlama, uluslararası hukuk veya insan hakları sözleşmelerinden değil ulus devletin kendisinden yani anayasadan kaynaklanmaktadır. ${ }^{19} \mathrm{Bu}$ bakımdan anayasanın devletteki ana rolü, bireylerin temel hak ve özgürlüklerini korumak için otolimitasyon ile iktidarı sınırlandırmaktır. ${ }^{20}$ Ancak anayasanın devletteki rolü nedir sorusuna tam bir cevap verebilebilmesi için öncelikle anayasanın ne olduğu sorusunun yanıtlanması gerekmektedir. ${ }^{21}$ Anayasa, maddi anlamda devletin temel organlarının kuruluş ve işleyişini belirleyen, şekli anlamda da hiyerarşik olarak en üstün olan ve zor değiştirilebilen hukuk kuralları bütünü olarak tanımlanabilir. ${ }^{22}$ Ancak bu tanım salt pozitivist bir tanımdır. Oysa anayasacılık, özgür toplumun herhangi bir şekilde köleleşmesini engellemeyi ve uygun bir anayasal düzenleme ile özgürlüğü kurumsallaştırmayı amaçlamaktadır. ${ }^{23}$

18 Kemal Gözler, Anayasa Hukukunun Genel Teorisi: Cilt 1 (Ekin Yayınevi 2011) 133; "Bir hareket olarak anayasacılık, polisi, ordusu, savaşları ve bunların sonucu kendini gerçekleştirme ve kendini ifade etme özgürlüğü üzerine getirdiği baskıcı sınırlamaları ile monarşik mutlakiyetçiliğe karşı yönelmiştir." Carl J. Friedrich, Sinırlı Devlet (Mehmet Turhan çev, Gündoğan Yayınları 1999) 17; "Anayasacılık, genel olarak keyfi yönetimi önleme çabalarını ifade etmektedir.” Britannica Dictionary, https://www.britannica.com/topic/constitutionalism Erişim Tarihi 19.01.2021; "Anayasac1lı, keyfi yönetimin antitezidir." Şahin (n 4) 311; "Yaygın olan anayasacılık teriminin iktidarı sınırlandırmak anlamında kullanılmasıdır." Erdoğan Keskin, Anayasa Hukukunda Anayasacılık Düşüncesi: Gelişimi ve Temel Unsurlarl (Adalet Yayınevi 2020) 28; "Anayasacılık: Anayasal yönetimi, yani sınırlı ve vatandaşların hak ve özgürlüklerine öncelik veren bir anayasaya dayalı idare biçimini savunmak.” Atilla Yayla, Siyasî Düşünce Sözlü̆̆̈̈ (2. Bası, Adres Yayınları 2003) 23.

19 T. Alexander Aleinikoff, 'Sovereignty Studies in Constitutional Law: A Comment' (2000) 17 (2) Constitutional Commentary 197, $197<$ https://core.ac.uk/download/pdf/217203098.pdf> Erişim Tarihi 01.01.2021; "Çağımızın önde gelen anayasa teorisyenlerinden Jon Elster, "Ulysses and Sirens" adlı eserinde, egemen toplumların ya da egemen kurucu meclislerin neden kendilerini bağlamak üzere bir anayasa yaptıklarını, Yunan mitolojisinde "Ulysses" efsanesi benzetmesiyle açıklamaya çalışmıştır. Bilindiği gibi, Ulysses, sirenlerin büyüleyici şarkılarının etkisiyle yoldan çıkmamak için kendisini, geminin direğine bağlamış, kürekçilerinin kulaklarına da balmumu tıkamıştır. İşte anayasalar, politik iktidarı ellerinde tutan yöneticileri yoldan çıkmalarını önleyecek direklerdir.” Aylin Kılıç Cepdibi, “İrade ve Egemenliğin Politik Alana Yansımasının Tiranik Sonuçları Üzerine Bir Değerlendirme’ in Saim Üye, Nadire Özdemir, Zeynep İspir, Funda Kaya, Elif Çağla Yıldız (edr) Hukuk Felsefesi ve Sosyolojisi Arkivi: 28. Kitap (İstanbul Barosu Yayınları 2019) 68; "Anayasanın kilit rolü, kendi kendini düşüncesiz tepkilerden ve ani hareketlerden korumak için sınırlandırmaktır." Jon Elster, 'Forces and Mechanisms in the Constitution-Making Process' (1995) 45 (2) Duke Law Journal 364, $382<$ https:// core.ac.uk/download/pdf/190850377.pdf> Erişim Tarihi 02.01.2021; “Senatör John Potter Stockton'un dikkat çektiği üzere 'anayasalar, insanların çıldırmış oldukları zamanlarda intihar ederek ölmemeleri için akılları başlarındayken kendilerini bağladıkları zincirlerdir'. Biz, anayasal kurallarla gelecekte yoldan çıkma ihtimalimize karşı kendimizi bağlarız." John E. Finn, Constitutions in Crisis: Political Violance and the Rule of Law (Oxford University Press 1991) 5.

20 Mustafa Erdoğan, Anayasal Demokrasi (13. Bas1, Siyasal Kitabevi 2017) 4; Paine de bireylerin temel hak ve özgürlüklerinin garanti altına alındığı yasalar tarafından yönetilmeyen ülkelerde uygulamada monarşi ya da mutlakiyetin devam ettiğini söylemektedir. "Seçimle işbaşına gelme sistemi de, eğer sonunda iş başına gelen sınırsız yetki kullanacaksa, doğal hakları ihlal edecekse, fiiliyatta monarşidir, mutlakıyettir." Thomas Paine, İnsan Haklarl (Mehmet Osman Dostel çev, İletişim Yayınları 2017) 20.

21 Sartori (n 4) 857.

22 Hatta Gözler, şekli kriteri doğru sayarak anayasanın tanımını şekli tanıma daha uygun bulmaktadır. Gözler'e göre içeriği çok farklı konulardan da oluşsa şekli kriterleri sağlayan düzenleme anayasa düzenlemesidir. Bkz. Gözler, Anayasa Genel Teori (n 18) 106.

23 Friedrich (n 18) 19. 
Dolayısıyla anayasacılığın asıl amacının iktidarı sınırlandırmak olduğu göz önünde bulundurulursa anayasa, iktidarı sınırlandırmak amaçlı devlet siyasal teşkilatlanmasını düzenlemelidir. ${ }^{24}$

Anayasa, devlet iktidarını farklı organlara bölüştürmek suretiyle karşılıklı bir denge sistemi kurarak iktidarı sınırlandırmaktadır. Burada da iktidarı sınırlandırmayı amaçlayan kuvvetler ayrılı̆̆ teorisi karşımıza çıkmaktadır. ${ }^{25}$ Yine anayasa, bireylerin temel hak ve hürriyetlerini koruma altına alarak iktidarı sınırlandırmaktadır. Sonuç olarak anayasanın devletteki rolü, maddi anlamda devlet iktidarını sınırlandırmak ve bireylerin temel hak ve hürriyetlerini güvence altına almaktır. Fransız İnsan ve Yurttaş Hakları Bildirgesinin 16. maddesinde "hakların güvence altına alınmadığ ve kuvvetler ayrılığına dayanmayan hiçbir toplumda Anayasa yoktur"26 ifadesi yer almaktadır. Bu amaçların gerçekleşebilmesi için anayasanın şekli anlamda da hiyerarşide en üstte ve zor değiştirilebilir olması gerekmektedir. ${ }^{27}$

İktidarın sınırlandırılması temel olarak kuvvetler ayrılığı ile sağlanabilir. Burada doğrudan aklımıza egemenliği bir bütün olarak gören halk egemenliği teorisi gelmektedir. Halk egemenliği teorisine göre egemenlik bölünüp farklı organlara verilemez. ${ }^{28}$ Bireylerin temel hak ve hürriyetleri anayasa ile güvence altına alınmak istenmektedir. Buna göre çoğunluk iradesine dayanarak yasa koyucu organ tarafindan çıkarılmış olsa bile bireylerin temel hak ve hürriyetlerini zedeleyici kanunların anayasaya aykırılığını denetleyen anayasal bir denetim organı gereklidir. Ancak bu da halk egemenliği teorisiyle bağdaşmamaktadır. ${ }^{29}$ Sonuç olarak anayasacılık ile halk egemenliği teorisi uyumlu değildir diyebiliriz. Kanaatimizce anayasacılığın amacı bir

\footnotetext{
24 "Anayasa, keyfi iktidarı sınırlandırmak amaçlıdır." Sartori (n 4) 857; "Bir anayasanın felsefi temeli ne olursa olsun, anayasa yapmanın önemli politik amacının özgürlük olduğunu söylemek gerekir.” Friedrich (n 18) 17; Buna karşılık keyfi iktidarı sınırlandırmak amacıyla yapılmayan anayasalar da mevcuttur. Bir tarafta Fransız İnsan ve Yurttaş Hakları Bildirgesinin 16. maddesinde belirtilen özellikleri taşımayan metinleri anayasa saymayan düşünceler varken diğer tarafta bu metinleri bir anayasa sayan düşünceler mevcuttur. Bu ikinci düşünceler ise bir devlette anayasa adı altında herhangi bir metnin olması durumunda o devleti anayasalı devlet olarak tanımlamakta ama anayasal devlet olarak görmemektedir. Dolayısıyla yaygın olan kullanıma göre anayasacılık, anayasanın keyfi iktidarı sınırlandıran bir metin olmasından bahisle, iktidarı sınırlandırmayı amaçlayan düşünceye denilmektedir. Buna karşılık anayasayı içeriğine bakmadan salt şekli anlamda düşünürsek anayasacılık bir devletin kendi anayasasına bağlılığı şeklinde anlaşlabilir. O devlet anayasal bir devlet olmasa bile... Ergun Özbudun'a göre anayasacılık, bir devletin kendi anayasasına uygun olarak hareket etmesi anlamına gelmektedir. Özbudun, bu çalışmada da iktidarı sınırlandırmak anlamında kullanılan anayasacılık kavramı yerine anayasalcılık kavramını önermektedir. Özbudun'a göre iktidarı sınırlandırmayı amaçlayan düşünce akımı anayasalcılıktır. Bkz. Ergun Özbudun, Anayasalcllık ve Demokrasi (2. Bası, İstanbul Bilgi Üniversitesi Yayınları 2015) 3; İktidarı sınırlandırmak ve bireylerin haklarını güvence altına almak amacıyla yapılmayan anayasa metinlerini de anayasa olarak kabul eden görüşler, anayasacılığı devletin kendi anayasasına bağlılık ya da devletin ana teşkilatlanmasını içeren anayasalar yapmak şeklinde tanımlamaktadır. Bu bakımdan anayasacılık, genel anlamda iktidarı sınırlandırmayı amaçlamak şeklinde değil de liberal, sosyalist ve İslami anayasacılık başlıkları altında incelenmektedir. Abdurrahman Eren, Anayasa Hukuku Dersleri: Genel Esaslar-Türk Anayasa Hukuku (2. Bası, Seçkin Yayınevi 2020) 97 vd.

25 Mehmet Turhan, 'Anayasacılık ve Kuvvetler Ayrılığı Kuramı' in Hayrettin Ökçesiz (ed) Hukuk Felsefesi ve Sosyolojisi Arkivi 2. Kitap (Afa Yayıncılık 1995) 107.

26 Declaration of Human and Civic Rights, https://www.conseil-constitutionnel.fr/sites/default/files /as/root/bank_mm/ anglais/cst2.pdf Erişim tarihi 29.10.2020.

27 "Yazılı, katı ve zor değiştirilebilir somut bir anayasası olmayan İngiltere için anayasasız anayasacılık tabiri kullanılmaktadır." Gözler, Anayasa Genel Teori (n 18) 135.

28 ibid 446.

29 ibid 447.
} 
bakıma halkın iradesini ya da diğer bir deyişle çoğunluğun iradesini anayasa denen üstün bir yazılı metinle sınırlandırmaktır. Bu nedenle de anayasacılık halk egemenliği teorisiyle çatışmaktadır.

\section{B. Egemenlik Kavramı}

Egemenlik, sözlükte "milletin ve onun tüzel kişiliği olan devletin yetkilerinin hepsi" anlamına gelmektedir. ${ }^{30}$ Yine egemenlik, farklı şekillerde "bir devletin sahip olduğu tüm insan gücünün birliği ve uygulaması" ya da "bir devletin kendi toprak parçasın üzerinde hesap vermesi gerekmeden istediği her şeyi bir yapabilme gücü" olarak tanımlanabilir. ${ }^{31}$ Özetle egemenliği, bir devletin en üstün ve mutlak gücü olarak ifade edebiliriz. Aslında egemenlik temel referansı siyasi olan bir kavramdır. ${ }^{32}$ Egemenlik kavramını kullanan ve tanımlayan kişiler de genellikle siyasi bir açıklama getirmeye çalışmışlardır. ${ }^{33}$

Egemenlik kavramını modern anlamda ilk kez kullanan Jean Bodin, egemenliği üç temel özellikle ifade etmektedir. Bodin'e göre egemenlik; mutlak, sürekli ve devredilmezdir. ${ }^{34} \mathrm{Bu}$ çalışmanın temel konusu olan anayasacılık, iktidarı sınırlandırmayı amaçladığı için ilk defa egemenliği modern anlamda kullanan Bodin'in egemenliğin kullanımını aslında sınırlı bir şey olarak gördüğüne de değinmek yerinde olacaktır. Bodin’e göre egemenliği kullanan tanrı buyruğunun ve

30 TDK Sözlük "Egemenlik", www.sozluk.gov.tr. Erişim tarihi 10.11.2020.

31 Law Dictionary "Sovereignty", www. dictionary.thelaw.com Erişim tarihi 10.11.2020.

32 Raia Prokhovnik, 'Internal/ External: The State of Sovereignty' (1996) 2 (3) Contermporary Politics 7, $7<$ https://doi. org/10.1080/13569779608454737> Erişim Tarihi 20.12.2020.

33 Ortaçağ boyunca tartışılmayan egemenlik kavramı, ticaretin artması ve burjuvazinin gelişmesiyle birlikte tartışılmaya başlanmıştır. Dolayısıyla egemenlik kavramı ve egemenlik teorisi modern çağla birlikte ortaya çıkmıştır. Zira önceleri iktidar yetkisi doğal olarak kralda, monarkta ya da tanrı adına yöneten dini kurumlarda, kilisedeydi. Daha sonraları parasal anlamda güçlenen burjuvazi, yönetimde yer almak istedi ve bu talebi reddedilince de egemen kimdir, egemenlik kimdedir tartışmaları ortaya çıkmaya başladı. Rıza Arslan, Siyaset Bilimine Giriş: Kavramlar (Dora Yayınevi, 2016) 68.

34 Saygılı (n 14) 186; "Bodin, egemenliğe bazı özellikler atfetmektedir. Bu özellikler; egemenliğin mutlak, sınırsız, sürekli, tek, bölünemez ve devredilemez oluşudur. Bodin'e göre; egemenlik, siyasi topluluğu birleștiren ve bir arada tutan güçtür. Egemenlik olmazsa siyasi topluluk parçalanır." Cemil Meriç, Umrandan Uygarlığa (28. Bası, İletişim Yayınları 2015) 189; "Egemenliği kavramsal olarak modern anlamda ilk kullanan isim Bodin olmakla birlikte bu kavramın doğmasından önceki düşünsel altyapıyı, orta çağın ahlak ve dini yerine politikayı benimseyen yeni bir sistemi savunan Machiavelli ortaya koymuştur.” Oktay Uygun, Devlet Teorisi (7. Bası, On İki Levha 2020) 181. 
doğal hukukun altındadır dolayısıyla bunlara uygun olarak davranmak zorundadır. ${ }^{35}$ Fakat bir diğer taraftan Bodin, egemenlik kavramını getirerek devletin başındaki kişiyi güçlendirmektedir. ${ }^{36}$ Hatta Bodin'in egemenlik kavramı, temelde milli egemenlik adını alarak günümüzde halkın çoğunluğunun ya da salt anlamıyla demokrasiyi sınırlandıran bir miras olarak kalmıştır. ${ }^{37}$

Bodin, egemenliği iki şekilde anlamaktadır. İlk anlamına göre egemenlik, soyut bir kavram olarak en üstün ve mutlak emretme gücüdür. İkinci anlamına göre ise siyasi iktidar olarak bu üstün gücün somutlaşmış görünümüdür. Bu bakımdan aslında egemenlik ile siyasi iktidar aynı kavramın farklı görünümleridir. ${ }^{38}$ Anayasacılığın temel amacı iktidarı sınırlandırmak olduğuna göre soyut anlamda egemenlik ile somut anlamda siyasi iktidar birbirinden ne kadar çok ayrışırsa sınırlandırma amacı o kadar çok gerçekleşecektir. Örneğin tanrı-kral düşüncesi üzerine kurulu bir monarşide soyut anlamda egemen de somut anlamda siyasi iktidar da aynı kişidir, kraldır. Bu durumda kralın sınırsız yetkili olduğu görülecektir. Aynı şekilde küçük çaplı bir site devlette doğrudan demokrasinin işlediğini düşünelim. Bu durumda da soyut olarak egemen olan genel irade ile somut olarak orada bulunan vatandaşların çoğunluğu yani siyasi iktidar aynı olacaktır. Dolayısıyla iktidarın sınırlandırılması düşüncesi burada da karşımıza çıkmayacaktır. Ancak milli egemenlik teorisine dayanan devlet modelinde soyut olarak egemen olan millet ve somut olarak siyasi iktidar birbirinden oldukça

35 Sarıca, Siyasi Düşünce (n 12) 96; "Egemenin yasama yetkisinin mutlak olduğunu fakat bu yetkisini kullanırken ilahi ve doğal yasalar ile sınırlandırıldığını belirten Bodin, bir çelişki gibi görünen bu yaklaşımını ilahi ve doğal yasaların her durumda adalet ilkesini içerdiğini varsayarak açıklamaktadır. Bodin'e göre prensin mutlak egemenliğinin sınırı ilahi ve doğal yasalardır, prens bunlarla bağlıdır." Serkan Ekiz, 'Jean Bodin'in Siyaset Felsefesinde Devlet ve Egemenlik' (2020) 22 (2) Dokuz Eylül Üniversitesi Hukuk Fakültesi Dergisi 633, 663; "Bodin egemen iradenin en üstün otorite olduğunu düşünür. $\mathrm{Bu}$ iradeyi sınırlayacak hiçbir güç yoktur. Şüphesiz ki tanrı devletten daha üstündür. Ancak tanrı adına kralları denetleme yetkisini kendinde göre kiliseden farklı olarak somut bir sınırı ifade etmez bu tanrı inancı.” Armağan Öztürk, 'Egemenliğin Cumhuriyetçi Yapı Sökümü: Machiavelli, Rousseau ve Ulus Devlet' (2020) (58) Muhafazakar Düşünce 85, 87. Günümüzde de egemenlik, klasik egemenlik anlayışından farklı olarak sınırlı bir egemenlik olarak anlaşılmaktadır. Tabi ki bu sınırlı oluş Bodin'in ifade ettiği doğal hukuk ve tanrı buyruğundan kaynaklı bir sınırlılıktan farklıdır. Modern devletin gelişimi çizgisinde anayasacılığın amacının gerçekleşmesi ve siyasi iktidarın sınırlandırılmış olmasının yanı sıra uluslararası insan haklarının gelişmesi de klasik egemenlik anlayışında esaslı bir değişim meydana getirmiştir. Hatice Derya Ormanoğlu, 'Modern Devletin Bir Unsuru Olarak Egemenlik ve Uluslararası Ceza Mahkemesi' (2018) 9 (4) İnönü Üniversitesi Hukuk Fakültesi Dergisi 245, 255; Örneğin; Avrupa Birliği gibi ulusalüstü topluluklar, devletlerin kendi egemenlik alanlarına da müdahale edebilmektedir. Özellikle insan hakları mahkemeleri, klasik egemenlik anlayışının değişimine en çarpıcı örnektir. "Egemenliklerini, belli alanlarda ulusalüstü olarak kabul edilen bir örgütlenmeye devreden üye devletler, bu belirlenmiş alanlar içinde kalmak koşuluyla, Topluluğun bir takım ișlem ve kuralları ile karșı karșıya kalmaktadır.” Bülent Yücel, 'Westphalia Anlaşmasından Nice Anlaşmasına: Egemenlik Kavramının Tarihsel Seyri ve Bir Prototip Olarak Avrupa Birliği’ (2006) 10 (1-2) Atatürk Üniversitesi Erzincan Hukuk Fakültesi Dergisi 165, 182.

36 Bodin, zamanının kademelendirilmiş feodal iktidar anlayışının aksine tüm yetkilerin kaynağını devletin başındaki kişiye veren bir teori geliştirmiştir. Feodal iktidar merkezlerinin kralın üstün iktidarına tabi kılınması, ulus devletin doğuşunun habercisidir. Levent Korkut, 'Ulus Devletin Ortaya Çıkışından Günümüze Kadar Kamu Hukukunda Egemenlik Kavramsallaştırmaları’ (2015) 2 (1) İstanbul Medipol Üniversitesi Hukuk Fakültesi Dergisi 31, 34.

37 Sarıca, Siyasi Düşünce (n 12) 97.

38 Anayurt (n 13) 243; “Jean Bodin, aslında monarşi savunucu biri olduğu için egemenlik kavramını da en üstün ve mutlak bir monark gücüyle özdeşleştirmek için ortaya atmıştır. Bodin'e göre aristokrasi ve demokrasinin harmanlandığı Aristotalesçi karma yönetim düşüncesi aynı anda hem zenginlerin fakirler üzerinde hem de fakirlerin zenginler üzerinde egemenlik kurmasıdır ki bunun da sürdürülebilir olması mümkün değildir. Dolayısıyla doğası gereği bunlardan birinin diğerine hâkim olmasıyla ya baskıcı bir oligarşi ya da çoğunluğun tiranlığı ortaya çıkacaktır. Sonuçta Bodin üstün ve mutlak güce sahip tek bir monarkın zengin-fakir çatışmasını sınırlayabileceğini düşünüyordu." Edward Andrew, 'Jean Bodin on Sovereingty' (2011) 2 (2) Republics of Letters: A Journal for the Study of Knowledge, Politics and the Art 75, $82<\mathrm{https}$ ://arcade.stanford. edu/sites/default/files/article_pdfs/roflv02i02_Andrew_060111_0.pdf > Erişim Tarihi 01.01.2021. 
ayrışmış durumdadır. Bu durumda iktidarın sınırlandırılması düşüncesi büyük oranda ortaya çıkmaktadır. ${ }^{39}$

Egemenlik kavramı denilince akla ilk gelen bir diğer isim Hobbes'tur. Hobbes da Bodin'e benzer bir egemenlik tanımı geliştirmiştir. Hobbes'a göre egemenlik; bölünemez, mutlak ve sınırsızdır. ${ }^{40}$ Sonuç olarak egemenlik kavramı incelendiğinde karşımıza çıkan en önemli özellik egemenliğin bölünemez olduğu ve egemenliğin bölünmesi durumunda ortadan kaybolacağıdır. Ancak egemenliğin kullanımı bakımından anayasal devletler, bazı bölüşmeleri öngörmektedir. Özellikle kuvvetler ayrilığına dayanan anayasal düzenlerde egemenliğin tek ve bölünmez olduğu ama kullanımın farklı organlara paylaştırıldığı söylenebilir. Bu çalışmanın konusu daha çok egemenliğin kaynağı bakımından ortaya konulmuş olan demokratik egemenlik teorileriyle ilgilidir. $\mathrm{Bu}$ nedenle egemenliğin bölünmezliğiyle ilgili tartışmaya bu çalışmada daha fazla yer verilmemektedir. Devlette egemenlik tek ve bölünemez olmakla birlikte egemenliğin görünümü iki farklı şekilde karşımıza çıkmaktadır. Yani egemenliğin iç ve dış olmak üzere iki şekilde görünümü mevcuttur. ${ }^{41}$

\section{Dış Egemenlik}

Devletlerin egemenliği, dış ilişkilerinde bağımsızlık olarak karşımıza çıkmaktadır. Dış egemenlik; devletlerin eşit egemenliği, birbirlerinin egemenlik alanlarına saygı duyması, birbirlerinin iç işlerine karışamaması ve kendi iradeleri dışında uluslararası bir sınırlamaya tabi tutulamaması anlamına gelmektedir. ${ }^{42}$ Dolayısıyla bir devlet egemenlik yetkisini kullanırken tamamen bağımsızdır ve hiçbir başka otoriteden izin istemek zorunda değildir. ${ }^{43}$

39 Her ne kadar milli egemenlik teorisi, ilk olarak burjuvazinin çıkarlarını savunmak amacıyla ortaya çıkmış olsa da günümüzdeki kazanmış olduğu anlam dolayısıyla tüm bireyler açısından faydalı bir şekilde yorumlanabilmektedir. İlk etapta burjuvazinin, zengin bir kesimin, yeni bir aristokratik sınıf olușturmasını amaçlayan ve bunu milli egemenlik teorisine dayandıran görüșler, belirli bir zenginliğe sahip olmayan vatandaşlara oy hakkı verilmemesini savunmaktaydı. Soyut bir kavram olan millet adı altında burjuvazinin egemenliğini meşrulaştırmak istemekteydi. Babeuf, Fransız devrimi sonrasında ortaya çıkan hukuki eşitliğin gerçek eşitlik olmadığını savunmuştur. Gerçekten aristokrasinin hukuki ayrıcalıklar sayesinde egemen güç olduğu eski dönemin yerini artık burjuvazinin parasal güç sayesinde yeni bir aristokrat sınıf gibi egemen olmak istediği bir dönem almıştır. Bu dönemde de soyut bir kavram olan millet ve milleti ancak bir burjuva azınlığın temsil edebileceği düşüncesi ortaya atılmıştır. Daha sonralarda uzun mücadeleler sonucu genel oy ilkesinin kabulü ve diğer demokratik gelişmelerle milli egemenlik teorisi de dönüşüme uğramıştır. Günümüzde ise milli egemenlik, siyasi iktidarın sınırlandırılması açısından oldukça önemli bir teorik temel halini almıştır. Alper Işık, 'Sieyes Hala Yaşıyor mu?' (2016) 22 (1) Marmara Üniversitesi Hukuk Fakültesi-Hukuk Araştırmaları Dergisi 183, 186 vd.; Sarıca, Siyasi Düşünce Tarihi (n 12) 153 vd.

40 Aysel Doğan, 'Hobbes’un Mutlak Egemenlik Hakkındaki İkilemi' (2004) (35) Liberal Düşünce 117, 118.

41 Özçelik (n 5) 59.

42 Ali Fuat Başgil, Esas Teşkilat Hukuku: Cilt 1 (Baha Matbaası 1960) 178.; Gözler, Anayasa Genel Teori (n 18) 432; Özçelik (n 5) 59; Tarihsel süreçte ortaçağdaki kilise hakimiyetinden kurtulan ve dişarıya karşı tam olarak bağımsız olduğunu gösteren monarşi (Fransa kralları) egemenlik kavramını ülke dışında kendilerinden üstün bir güç kabul etmediklerini ifade eden hukuksal kavram olarak kullanmışlardır. Kapani, Politika Bilimi (n 17) 65.

43 Gözler, Anayasa Genel Teori (n 18) 433; Tabi ki globalleşme, uluslarüstü birlikler, yerel özerklikler, sivil toplumun gelişmesi ve bunların uluslararası mekanizmalarla irtibatı, uluslararası mahkemelerin ortaya çıkması vb. gelişmelerle birlikte klasik egemenlik anlayışından sapmalar yaşanmaktadır ve Bodinci, Westfalyan egemenlik anlayışı hakkında artık sorgulamalar ortaya çıkmaktadır. Artık ulus devletlerin gerçekten tam anlamıyla bağımsız hareket edebilip edemedikleriyle ilgili büyük soru işaretleri ve bu sorulara dair önemli tartışmalar mevcuttur. Ancak bu çalışmanın konusuyla ilgili olmadığı için bu tartışmalara girmiyoruz. 


\section{2. İç Egemenlik}

İç egemenlik, devletin kendi toprak parçası ve bu toprak parçasında yaşayan insanları üzerindeki en üstün egemenliğini ifade etmektedir. ${ }^{44}$ Egemenlik, ilk olarak düzeni sağlayan hukuk kurallarını yapmayı ve uygulamayı içermektedir. ${ }^{45}$ İç egemenliğe göre devlet, ülkesinde yaşayan insanlara emir verici hukuk kurallarını yapma ve uygulama tekeline sahiptir. ${ }^{46}$ Burada egemenlik, iki anlamda kullanılmaktadır. İlk olarak egemenlik, devlet iktidarının kendisi anlamına gelmektedir. ${ }^{47}$ İkinci olarak devlet iktidarının özellikleri anlamında egemenlik, en üstün, sınırsız, bölünemez ve devredilemez özellikleri belirtmektedir. ${ }^{48}$

\section{Anayasacılığın Dış Egemenlik ve İç Egemenlik ile İlişkisi}

Kanaatimizce anayasacılık doğrudan iç egemenlikle ilişkilidir. Anayasacılık ile devletin kendi toprak parçası ve burada yaşayan vatandaşları üzerindeki iktidarının sınırlandırılması amaçlanmaktadır. Yoksa dış egemenlik bakımından tam bağımsız bir ulus devlet anlayışıyla sıkı bağ içerisinde olan anayasacılık, iktidarın dışarıdan bir sınırlamaya tabi olmasını istememektedir. Kısacası anayasacılık, iç egemenlikte egemenin kendi kendini sınırlandırmasını amaçlamaktadır. Bunu da önceleri bölünemez olarak görülen egemenliğin kuvvetler ayrılığına dayanan ve birbirini dengeleyen organlar eliyle kullanılmasıyla ve ayrıca iktidarın da uymakla mükellef olduğu en üstün anayasa normunun bireylerin temel hak ve hürriyetlerini güvence altına almasıyla sağlamayı amaçlamaktadır. ${ }^{49}$

\section{Egemenin Kendi Kendini Sınırlandırabilip Sınırlandıramayacağı Problemi}

Egemenliği ilk olarak kavramlaştıran Bodin, onu hem soyut bir kavram olarak görmekte hem de somutlaşmış bir siyasi iktidar olarak görmektedir. Bu bakımdan aslında egemen ile siyasi iktidar aynı kavramın farklı görünümleridir. ${ }^{50}$ Burada da egemenin kendi kendini gerçekten sınırlandırabilip sınırlandıramayacağı problemi ortaya çıkmaktadır. Carl Schmitt, Bodin'i yukarıda incelediğimiz meşhur

\footnotetext{
44 Monarşi (Fransa kralları) egemenlik kavramını ülke içinde kendi iktidarlarına rakip olabilecek bir iktidar tanımadıklarını ifade eden bir hukuksal kavram olarak kullanmışlardır. Kapani, Politika Bilimi (n 17$) 65$.

45 Prokhovnik (n 32) 7.

46 Özçelik (n 5) 59.

47 “Örneğin Jean Bodin'e göre, egemenlik, devletin kanun yapmak, savaş veya barış ilan etmek, yargılama yapmak, para basmak, vergi toplamak gibi yetkilerinden oluşur." Gözler, Anayasa Genel Teori (n 18) 435.

48 ibid 435.

49 "Dolayısıyla anayasacılık, dışarıdan bir sınırlamayı içermemektedir. Yine anayasacılıkla bahsi geçen temel hak ve hürriyetler, uluslararası hukuk veya insan hakları sözleşmelerinden kaynaklanmamaktadır.” Aleinikoff (n 19) 197.

$50 \quad$ Anayurt (n 13) 242; "Carl Schmitt de siyasi iktidar ile egemen arasındaki ayrımı ortadan kaldırmaktadır. Schmitt, siyasi iktidarı güçlendirmeye ve Aydınlanma devrimleriyle monarşiden alınan şeyleri siyasi iktidarda tekrar ele geçirmeye çalışmaktadır." Anne Norton, 'Pentecost: Democratic Sovereingty in Carl Schmitt' (2011) 18 (3) Constellations 389, 389 <https://doi.org/10.1111/j.1467-8675.2011.00653.x> Erişim Tarihi 25.12.2020.
} 
egemenlik tanımı dolayısıyla değil başka bir eserinde vurguladığ1 "egemen, kendi koyduğu hukuk kurallarıyla ne ölçüde bağlıdır" sorusu dolayısıyla modern devlet teorisinin başlangıcına koymaktadır. ${ }^{51}$ Örneğin; bir monarşide bir fermanla kendini sinırlandırdığını ilan eden kral, aslında her zaman bu sinırlandırmayı kaldırma yetkisini de kendinde barındırmaktadır. Ya da tamamen halk egemenliği teorisine dayanan bir demokraside bir kanunla kendini sınırlandırdığını ilan eden çoğunluk, aslında her zaman bu sınırlandırmayı başka bir çoğunluk kararıyla kaldırma yetkisini de kendinde barındırmaktadır. Böyle bir sınırlandırmanın geri alınması hali, genellikle olağanüstü bir durumun ortaya çıktığı bahanesiyle olacaktır.

Modern anayasal gelişmelere dair tüm eğilimler, iktidarı ya da egemeni sınırlandırmaya odaklanmış olsa da bu düşüncelerin her zaman bir istisna hali içerdiği görülmektedir. Schmitt'e göre istisnaların tamamen ortadan kaldırılıp kaldırılamayacağı ise hukuki bir soru değildir..$^{52}$ Fakat burada Schmitt'in "egemen, istisna hâline karar verendir" 53 tanımından da hareketle egemenliğin kaynağının ne olduğu sorusu önem arz etmektedir. Zira yukarıdaki paragrafta verilen örneklerde de görüleceği üzere egemenliğin kaynağı tanrı ise ve tanrı adına egemen kral ise zaten aslolan sınırsız iktidardır. Tarih boyunca kralların kendilerini sınılandıracak bir düzenlemeleri kabul etmeleri az görülen bir durumdur. Yine de böyle bir sınırlama varsa o kralın bunu ortadan kaldırması pek zor olmayacaktır. Dayanılan egemenlik anlayışı bunu gerektirmektedir. Hakeza aynı şekilde egemenliğin kaynağını halk olarak gören ve çoğunluğun genel iradesinin egemen olduğu bir devlette de aslolan genel iradenin sınırsız iktidarıdır. Sınırlı bir çoğunluk iktidarı kabul edilmiş olsa bile, kanunların çıkarılırken uyulması gereken sınırlamalar düzenlenmiş olsa bile çoğunluğun bu sınırlamayı kaldırması zor olmayacaktır. Burada da dayanılan egemenlik anlayışı bunu gerektirmektedir.

Schmitt'in eleştirisi, liberal burjuvazi eleştirisidir. Schmitt'in eleştirişi, görünürde sınırlı bir iktidar düzeni sunuyormuş gibi görünen anayasal düzenlerin aslında içinde barındırdıkları istisna hali nedeniyle hiç de göründükleri gibi olmadığı üzerinedir. Tersten okunduğunda egemen olan burjuvazinin, kendi çıkarlarını tehdit eden bir durum ortaya çıktığında istisna haline karar verip kendi ilkelerini bile yok sayacağı anlaşılabilir. Anayasacılık hem halkın çoğunluğuna karşı hem de aristokrasi ve monarşiye karşı kendi çıkarlarını güvence altına almak isteyen burjuvazinin millet soyut kavramı üzerinden sınırlı bir iktidar kurmak istemesidir. Ancak bu sınırlı iktidar

\footnotetext{
1 Carl Schmitt, Political Theology: Four Chapters on the Concept of Sovereignty (George Schwah çev, The University of Chicago Press 2005) 8; Böylece Schmitt devlet içinde siyaseti çok önemli bir noktaya koymaktadır. Cem Eroğul'a göre de devlet eyleminin tümü siyasettir. Öznel bir benzetme yapılacak olursa kişi ne yapıyorsa odur. O halde devlet ne yapmaktadır sorusuna genellikle siyaset cevabı verilmektedir. Devletin yaptığı işe genel olarak siyaset adı verilmektedir. Cem Eroğul, Devlet Nedir? (İmge Kitabevi 1990) 23; "Siyaset üretim dışında kalan ancak üretimin sürdürülebilmesi ve geliştirilebilmesi için toplumsal çapta yürütülmesi zorunlu olan işlerin toplamıdır.” Eroğul, Anatüzeye Giriş (n 14) 1.

$52 \quad$ Schmitt (n 51) 7.

53 ibid 5 .
} 
düşüncesi, aslında burjuvazinin kendi kendini sınırlandırmak istemesi anlamına gelmemektedir. Egemen sınıf olan burjuvazinin hiçbir zaman kendi iktidarını sınırlandırmayı amaçlamadığını söyleyebiliriz. Anayasacılık aslında burjuvazi değerlerinin hüküm sürmesini sağlamaktadır. Örneğin; mülkiyet hakkının kutsal sayılıp anayasal güvence altına alınmış olması, bir iktidarı sınırlandırmaktan ziyade, tam tersine güçlenip kendine ekonomik iktidar sağlayan burjuvazinin bu iktidarını hiçbir başka gücün sınırlandıramayacağını güvence altına almak amacını gütmektedir. Yine aynı şekilde ulus devletin, kendi varlığını tehdit eden durumlar karşısında ne pahasına olursa olsun kendini savunacağı da açıktır. Dolayısıyla ulus devlet ve burjuvaziyle sıkı ilişki içerisinde olan anayasacılığın asıl amacı, egemen sınıfın kendi iktidarını sınırlandırmak değil geçmişteki tek kişinin (monarşi) ve bir azınlığın (aristokrasi) yanı sıra gelecekteki halk çoğunluğunun (halk egemenliği) kendi temel değerlerine dokunmalarını engellemek olduğu şeklinde okunabilir. Böylece zaten egemen olmayan demokratik çoğunluğun egemen olan sınıfın çıkarları lehine susturulması, egemenin aslında kendi kendini sınırlandırmayı amaçlamadığı şeklinde yorumlanabilir. ${ }^{54}$

\section{Egemenliğin Kaynağı Bakımından Egemenlik Teorileri}

Egemenlik teorileri, egemenliğin kaynağını açıklamak ve devlet gücünü elinde bulunduran kişilerin meşruiyetinin nereden geldiğini izah etmek için ortaya atılmıştır. ${ }^{55}$ Devletin, belirli bir insan topluluğunun belirli bir toprak parçası üzerinde egemen olması sonucu var olduğunu söyledik. Dahası devlet, en üstün ve mutlak egemenlik gücüne sahiptir dedik. Peki bu egemenliğin kaynağı nedir diye sorduğumuzda karşımıza iki ayrım çıkmaktadır. İlk olarak egemenliği tanrıya dayandıran teokratik egemenlik teorilerine göre egemenlik tanrıya aittir ve bütün iktidarlar tanrıdan gelmektedir. ${ }^{56}$ Demokratik egemenlik teorilerine göre ise egemenlik insanlara aittir ve egemenliğin kaynağı beşeridir. ${ }^{57}$

\section{Teokratik Egemenlik Teorileri}

Egemenliğin nereden geldiğine dair klasik egemenlik teorileri ortaya atılırken ilk olarak tanrıya ve dinlere başvurulmuştur. ${ }^{58}$ Teokratik egemenlik teorilerine göre her ne kadar egemenlik tanrıya ait ise de bu egemenliğin yeryüzündeki kullanıcıları krallardır. ${ }^{59}$ Aslında zaten devleti tanımlarken kullanılan unsurlardan hareket edildiğinde bu durumun kabulü zorunludur. Zira devletin temel unsurlarından biri olarak egemenlik kabul edilmekte ve daha sonra bu egemenliğin meşruiyet

\footnotetext{
Norton (n 50) 390.

55 Özçelik (n 5) 59.

56 Gözler, Anayasa Genel Teori (n 18) 441.

57 ibid 442

58 Kapani, Politika Bilimi (n 17) 78

59 “O halde krallar da iktidarlarını doğrudan doğruya tanrıdan, onun kutsal iradesinden alırlar." ibid 79.
} 
kaynağını açıklamak amacıyla egemenlik teorileri ortaya atılmaktadır. Bir devletin var olabilmesi için insan ve toprak maddi unsurlarının yanı sıra bu insanların o toprak parçası üzerinde bir egemenliğinin var olması da gerekmektedir. Dolayısıyla egemenliği kullananlar her zaman insanlardır. Hatta ileride teokratik egemenlik teorileri açıklanırken her ne kadar egemenliği tanrı adına kullananın bir kişi olduğu durumlara yer verilse de bu durumlarda bile aslında egemenliğin meşruiyeti, o toprak parçası üzerindeki insanların bu bir kişinin tanrıdan yetki aldığını kabul etmesine dayanmaktadır. Teokratik egemenlik teorilerinden bazıları tanrının egemenliği kullanacak kişiyi doğrudan belirlediğini ileri sürülmektedir. Ancak bu durumda dahi egemenlik, o toprak parçasındaki insanların egemenliği kullanan o tek kişiyi meşru kabul etmesine dayanmaktadır. Başka bir ifadeyle söz konusu toprak parçası üzerinde yaşayan insanların egemenliğin kullanılmasını tanrının o kişiye verdiğini kabul etmesi, aslında gerçek meşruiyet sebebidir.

Teokratik egemenlik teorileri, genellikle iki başlık altında incelenmektedir. İlki doğaüstü ilahi hukuk doktrinidir. Buna göre, egemenliği kullanacak kişiyi doğrudan tanrı belirlemekte yani egemenlik bir ülkede tanrının seçtiği kişiye verilmektedir. ${ }^{60}$ $\mathrm{Bu}$ teoriye göre egemenliğin kaynağı olan tanrı, onu yeryüzünde kullanacak olan kişileri de doğrudan belirlemektedir. Dolayısıyla bu teoriye göre egemenliği kullanan kişinin, örneğin kralın, ülkedeki halka karşı hiçbir sorumluluğu yoktur. Ancak kanaatimizce her ne kadar bu teori ülke üzerindeki insan unsurunun egemenlik üzerindeki etkisini yok saysa da gerçekte durum böyle değildir. Zira bu teori var olan gerçeklikten hareketle ortaya atılmıştır. Ortada belirli bir insan topluluğu ve belirli bir toprak mevcuttur. Buradaki insan topluluğu, kralın egemenliği tanrıdan doğrudan almış olduğunu kabul ederek egemenliğin kullanımını zımnen krala bırakmaktadır.

Teokratik egemenlik teorilerinden bir diğeri ise providansiyel ilahi hukuk doktrinidir. Bu teorinin temel düşünürü Aquinalı Thomas, iktidarı ilahi bir kanunla sınırlandırarak aslında keyfi iktidarı önlemeyi amaçlamaktadır. Bu teoriye göre egemenliğin kaynağı tanrı olmakla birlikte onu yeryüzünde kullanan kişiler, insanlar tarafından belirlenmektedir. Başka bir deyişle "bütün iktidarlar, tanrıdan halk aracılığıyla gelir". ${ }^{61}$ Teokratik egemenlik teorileri her ne kadar metafizik nitelikte olsa da providansiyel ilahi hukuk doktrini, doğaüstü ilahi hukuk doktrinine göre daha gerçekçi görünmektedir. Bu teori, var olan gerçekliği daha fazla kabul edip insan unsuruna daha fazla önem atfetmektedir. Ancak bu teori de her halükarda tanrıya dayanmaktadır. Bu teoriye göre egemenliği kullanacak kişiler, insan unsuru tarafından beşeri olaylarla seçilmektedir ancak bu olaylar görünmez bir elle tanrı tarafından tasarlandığı için nihai kaynak tanrıdır. Başka bir ifadeyle iktidarlar, dolaylı da olsa, tanriya dayanmaktadır.

\footnotetext{
60 Erdoğan Teziç, Anayasa Hukuku (24. Bası, Beta Yayınevi 2020) 93; Gözler, Anayasa Genel Teori (n 18) 441.

61 Münci Kapani, Kamu Hürriyetleri (7. Bas1, Yetkin Yayınları 1993) 23 vd.
} 


\section{Teokratik Egemenlik Teorilerine Dayanan Devlet Modeli: Anayasasız Devlet}

Yukarıda da belirtildiği gibi anayasacılık, egemenliği kullananın iktidarını sınırlandırmayı amaçlamaktadır. Bu bakımdan teokratik egemenlik teorilerine dayanan devletlerde böyle bir düşüncenin olması düşünülemez. Egemenliğin kaynağının tanrısal olarak düşünüldüğü zamanlarda iktidarı kullanan kralın kendisini ilahi kaynaklı görmesi ve yetkisini tanrıdan aldığını ilan etmesi yeterliydi. ${ }^{62} \mathrm{Bu}$ şekilde düşünülen teokratik egemenlik teorilerine göre egemenliğin kaynağı tanrı ise ve egemenliği kullanan da tanrıdan aldığ yetkiyle hareket ediyorsa burada ancak dini kurallara uygunluk bakımından bir sınırlandırma düşünülebilir ki bu da çalışma konusuyla ilgili değildir. Ayrıca egemenlik kullanım hakkını bizzat tanrıdan almış birinin iktidarını kim hangi yetkiyle sinılandıracaktır? Bu devlet modelinde iktidarı kullananları sinırlayan bir anayasa bulunmamaktadır. Bu tür devletlerde devlet teşkilatını düzenleyen bir kurallar bütünü olsa bile bu, anayasacılık anlamında bir anayasa olarak kabul edilemez. Buna karşılık örneğin milli egemenlik teorisinde millet adına egemenliği kullanan organlar ve hatta yaşayan halkın çoğunluğu bile egemenliğin asıl kaynağı olan millet soyut kişiliği adına sınırlandırılabilecektir.

\section{Demokratik Egemenlik Teorileri}

Tanrısal ve dini kaynaklı egemenlik teorilerinin zamanla geçerliliğini yitirmesi sonucunda egemenliğin halka ait olduğu görüşler ve demokratik egemenlik teorileri, teokratik egemenlik teorilerinin yerini almıştır. ${ }^{63} \mathrm{Bu}$ teorilere göre artık egemenlik tanrısal değil beşeri kaynaklıdır. ${ }^{64}$ Artık iktidarın meşruiyeti de insana dayanmaktadır. Böylece demokratik egemenlik teorilerine geçilmiştir. Buna bağlı olarak da egemenliğin kaynağı konusunda metafizik açıklamalar bırakılmış, beşeri ve rasyonel açıklamalara başvurulmaya başlanmıştır. Demokratik egemenlik teorileri ise "milli egemenlik" ve "halk egemenliği" olmak üzere iki ayrı teoriye ayrılmaktadır. ${ }^{65} \mathrm{~K}$ ssaca halk egemenliğine göre halk, belirli bir anda yaşayan bireylerin toplamıken milli egemenliğe göre millet belirli bir anda yaşayan bireylerin, geçmişte yaşamışların ve gelecekte yaşayacakların toplamıdır. Bu çalışmanın ikinci bölümünde milli egemenlik ve halk egemenliği teorileri ayrıntılı olarak incelenecektir.

\footnotetext{
62 "Hükmetmek inandırıcı olmayı gerektirir. Nasıl ki günümüzde temsilcilerin, halkın sesi olduğuna inandırılan bir milli egemenlik tasavvuru mevcutsa geçmişte de kralın tanrının sesi olduğuna inanılmaktaydı. Kralın ilahi kaynaklı olduğuna, yanlış yapmayacağına, tanrının sesi olduğuna inanılan bir egemenlik anlayışı mevcuttu.” Edmund S. Morgan, Inventing the People: the Rise of Popular Sovereignty in England and America (W. W. Norton and Company 1989) 13.

${ }^{63}$ Mustafa Koçak, Batı'da ve Türkiye'de Egemenlik Anlayışının Değişimi: Devlet ve Egemenlik: Eski Kavramlar-Yeni Anlamlar (Seçkin Yayınları 2006) 110.

${ }_{64}$ "Aslında demokratik egemenlik teorilerinin demokratik bir rejime yol açıp açmayacakları fevkalade tartışmalıdır. O nedenle bu teorilere "beşeri egemenlik teorileri” demek daha doğru olur." Gözler, Anayasa Genel Teori (n 18) 442.

65 ibid 442.
} 


\section{Egemenliğin Kaynağı Ne Kadar Geniş Bir Tabana Yayılırsa Egemenliği Kullanan İktidar da o Kadar Çok Sınırlandırılır}

Teokratik egemenlik teorilerine göre egemenliğin kaynağı tanrıdır. Dolayısıyla bütün iktidarlar tanrıdan gelmektedir. Bu bakımdan egemenliği kullanan iktidarın en geniş ve en sınırlandırılamaz yetkilere sahip olduğu devletler teokratik egemenlik teorisine dayanan devletlerdir. Kanaatimizce egemenliğin kaynağı tek bir varlıktan, tek bir kişiden geliyorsa orada iktidarı sınırlanması en zordur. Buna karşılık demokratik egemenlik teorilerine göre egemenliğin kaynağ 1 beşeridir ve çok sayıda kişilerden oluşmaktadır. Halk egemenliği teorisine göre halk, belirli bir anda yaşayan bireylerin toplamıdır. Buna göre zaten iktidar otomatik olarak daha az keyfi bir hale bürünmektedir. Egemenliğin kullanım yetkisini tanrıdan alan tek bir kişidense halkın çoğunluğu çok daha az keyfi bir iktidar sürecektir. Fakat burada da çoğunluk iradesini sinırlandırmak mümkün görünmemektedir. Son olarak ise milli egemenlik teorisine göre millet belirli bir anda yaşayan bireylerin, geçmişte yaşamışların ve gelecekte yaşayacakların toplamıdır. Dolayısıyla egemenliğin kaynağı milli egemenlik teorisinde en geniş tabana yayılmakta ve çok büyük bir genişliğe sahip soyut bir kişilik olan millete dayanmaktadır. Milli egemenlik teorisine göre artık belirli bir anda yaşayan bireylerin çoğunluk iradesi bile geçmiş ve gelecek kuşaklar adına tek başına karar veremez nitelikte sınırlıdır. Bu soyut millet kişiliğinde yetki alan organlar birbirlerini dengelemek suretiyle iktidarı sınırlandırmaktadır. Yine anayasa mahkemesi gibi organlar, geçmiş ve gelecek kuşakların iradesine aykırı belirli bir andaki çoğunluğun iradesini sınırlandırmaktadır. ${ }^{66}$ Sonuç olarak egemenliğin kaynağının en geniş tabana yayılmış bir şekilde soyut bir kişilik olan millete dayandığı milli egemenlik teorisi, anayasacılıkla en ilişkili teoridir. ${ }^{67}$

\section{Demokratik Egemenlik Teorileri: Milli Egemenlik ve Halk Egemenliği}

\section{A. Milli Egemenlik}

Demokratik egemenlik teorilerine göre egemenlik artık tanrısal kaynaklı olmaktan çıkmış ve beşeri bir hale gelmiştir. İnsanların yönetilebilmesi için artık daha rasyonel

\footnotetext{
Gözler, Anayasa Genel Teori (n 18) 444.

$67 \mathrm{Bu}$ çalışmanın konusuyla ilgili olmamakla birlikte bir diğer örnek olarak günümüzde uluslararası insan hakları, iktidarı etkin bir şekilde sınırlandırmaktadır. 1789 Fransız devrimi, yani burjuva devrimi, sonrasında soyut bir 'millet' kavramı üreten ve 'milli egemenlik' adı altında iktidarı sınırlandırmayı amaçlayan burjuvazinin yerini günümüzde çok daha geniş bir soyut 'insan' kavramı üreten ve 'insan hakları' adı altında iktidarları çok daha sınırlı hale getiren uluslarüstü ya da küresel bir burjuvazi almaktadır diyebiliriz. Burjuvazinin kendi mülkiyetini koruyacak olan siyasal otoritelerin, kendine karşı da olabildiğince sınırlı iktidara sahip olmasını istemesi başka bir çalışmanın konusudur. Fakat aynı teori çerçevesinde değerlendirildiğinde evrensel bir soyut 'insan' kavramına dayanan düşünce çok daha geniş bir çerçeveye yayıldığı için iktidarları daha fazla sınırlandıracaktır. Zira artık iktidarın sınırlandırılması, bireyin o millete ait bir vatandas olmasından dolayı sahip olduğu haklardan değil evrensel nitelikli bir insan topluluğuna ait bir insan olmasından dolayı sahip olduğu haklardan kaynaklanmaktadır. Ki bu insan topluluğu da -aynı milli egemenlik teorisinin ulus devlet düzeyinde kabul ettiği gibi- küresel düzeyde sadece yaşayan bireylerin toplamı değildir aksine geçmişi, bugünü ve geleceği kapsayan soyut bir kavramdır.
} 
teorilere inandırılması gereği ortaya çıkmıştır. ${ }^{68}$ İlk olarak milli egemenlik teorisi, egemenliğin millete ait olduğunu savunmaktadır. ${ }^{69} \mathrm{Bu}$ teori, Fransız Devrimi döneminde, ilk olarak Gabriel Bonnot de Mably tarafından geliştirmiş ve daha sonra Emmanuel Joseph Sieyes tarafından sistemli hale getirilmiştir. ${ }^{70}$ Millet kavramının ne anlama geldiğini anlamak içinse Sieyes'in görüşlerine bakmak gerekmektedir.

\section{Sieyes'in Görüşleri ve Millet Kavramı}

Milli egemenlik teorisinin arka planındaki en önemli düşünür Sieyes’tir. Fransız devriminde de önemli bir rol oynamış olan Sieyes, Rousseau ile bazı önemli konularda ortak yönler barındırsa da birçok konuda Rousseau'dan ayrılmaktadır. ${ }^{71}$ Devlet egemenliğinin meşruiyetinin insanlara dayanması gerektiğini savunan Sièyes, egemen olanı bir millet olarak düşünmektedir. ${ }^{72}$ Sièyes, millet egemenliği kavramının kurucusu kabul edilmektedir. Sieyes'in tanımına göre millet, kendisini meydana getiren gerçek kişilerin toplamından farklı ve onların üstünde soyut bir kişiliktir. ${ }^{73}$ Milli egemenlik anlayışına göre egemenlik, bir devlette yaşayan tek tek vatandaşlara değil hem şimdi yaşayan hem geçmişte yaşamış hem de gelecekte yaşayacakların toplamına aittir. ${ }^{74}$ Dolayısıyla dikkat edilecek olursa bu yaklaşıma göre egemenliğin ait olduğu millet, bir bütündür. Yani egemenliğin tek tek kişilere ait olduğu düşünülemez ve kişilerin tek başlarına hiçbir güçleri yoktur. Zaten bu yaklaşıma göre millet, sadece bugünü değil geçmişi ve geleceği de kapsayan bir soyut bir kişilik olduğu için bir bütün olarak düşünülmek zorundadır. Bu soyut kişiliği bütün olarak bir araya toplamak mümkün değildir ve milleti somut olarak göremeyiz. Milli egemenliğin kullanılmasından bahsederken kişilerin iradelerinden ayrı ve onların iradelerinden üstün bir iradeden bahsedilmelidir. Yani bu bütün soyut kişilik olan milleti, yaşayan

\footnotetext{
68 Morgan (n 62) 13.

69 Gözler, Anayasa Genel Teori (n 18) 443.

70 Adnan Küçük, 'Egemenlik (Hakimiyet), Halk Egemenliği ve Milli Egemenlik Tartışmaları ve Egemenlik Anlayışında Esaslı Dönüşüm' (2015) 0 (6) Uyuşmazlık Mahkemesi Dergisi 311, 323.

71 Örneğin Sieyes "Tiers Etat Nedir?" makalesinde şöyle demektedir: "Bir siyasî topluluk, üyelerin tümünden başka bir şey olamaz. Bir millet millet olmamağa veya belirli bir tarzda millet olmağa karar veremez. Çünkü bu her hangi başka bir tarzda millet, millet olmayacak demektir. Ayni veçhile, bir millet, müșterek iradesinin artık müșterek iradesi olmak vasfını kaybetmesine karar veremez. Basitliği budalalık derecesinde görülecek olan bu kaziyeleri bunlardan çıkarılmak istenilen neticeler düşünülmezse belirtmek durumunda kalmak acıdır. İmdi, bir millet hiç bir zaman müşterek iradeye yani çokluğa ait hakların azınlığa geçmesine karar vermiș olamaz. Müșterek irade kendi kendisini tahrip edemez. Eşyanın tabiatını değiştiremez, ve azınlık oyunun çokluk oyu olmasını sağlıyamaz.” Emmanuel Sieyes, 'Tiers Etat Nedir?' Süheyp Derbil (çev) (1951) 8 (1) Ankara Üniversitesi Hukuk Fakültesi Dergisi 126, 190. Görüldüğü üzere Sieyes’in bu görüşleri, Rousseau'nun halkın çoğunluğunu ve genel iradeyi öncelediği görüşlerine benzemektedir. Ancak Sieyes, ortaya attığ millet kavramının geçmişi ve geleceği de kapsayan soyut bir kavram olması nedeniyle Rousseau'dan ayrılmaktadır. Yine çalışmanın sonraki kısımlarında da bahsedileceği üzere Rousseau da bazen genel iradeyi ayrı bir soyut irade gibi tanımlamaya girişerek Sieyes'in görüşlerine yaklaşmaktadır.

72 Gülce Tarhan, 'Rousseau ve Sieyes'de Egemenlik Kuramı' (2009) 2 (4) ETHOS: Felsefe ve Toplumsal Bilimlerde Diyaloglar 1,14 .

73 Hüseyin Nail Kubal1, Anayasa Hukuku Dersleri: Genel Esaslar ve Siyasi Rejimler (İstanbul Üniversitesi Hukuk Fakültesi Yayınları 1969) 198; Özçelik (n 5) 99.

74 Özçelik (n 5) 63; Gözler, Anayasa Genel Teori (n 18) 443; Hamza Eroğlu, 'Milli Egemenlik İlkesi ve Anayasalarımız' (1984) 1 (1) Atatürk Araştırma Merkezi Dergisi 137, 138.
} 
insanların iradesinden üstün ve başka bir irade olan millet iradesi temsil etmektedir. ${ }^{75}$ Sieyes'e göre Anayasa da millet iradesine dayanacak ve devlet, anayasa tarafından millet temeli üzerine inşa edilecektir. ${ }^{76}$

$\mathrm{Bu}$ çalışmanın konusu egemenlik teorileri ve anayasacılık olduğuna göre milli egemenlik teorisinin kurucusu Sieyes hakkındaki bazı bilgilere yer vermekte fayda bulunmaktadır. Örneğin Prof. Barthelemy, "Sieyes bir filozof, bir ahlakçı ya da bir iktisatçı değil, bir anayasacı ve kafasının içinde bir anayasa taşıyor" demektedir. ${ }^{77}$ $\mathrm{Bu}$ çalışmada da milli egemenlik teorisiyle anayasacılığın arasında sıkı bir ilişkinin olduğu söylenmektedir. Hatta -halk egemenliğinin aksine- anayasacılık, halkın çoğunluğunun iradesini sınırlandırmayı amaçlamaktadır. Her ne kadar günümüzdeki anayasaların iktidarı sınırlandırma amacıyla burjuva düzenini hukukileştirmek isteyen Sieyes'in amacı farklı olsa bile sonuçta milli egemenlik teorisi anayasacılıkla ve iktidarın sınırlandırılması meselesiyle yakından ilgilidir. ${ }^{78}$ Sonuç olarak; Sieyes'in milli egemenlik teorisine göre millet soyut bir kişiliktir ve milleti temsilciler temsil etmektedir. Temsilcilerin iradesi ise seçmenlerden alınan talimatla değil anayasayla sınırlandırılmıştır. ${ }^{79}$

\section{Milli Egemenlik Teorisinin Temel Özellikleri}

Milli egemenliğe göre temsili demokrasi teorik bir zorunluluk olarak karşımıza çıkmaktadır. ${ }^{80}$ Temsili demokrasi ile seçilen temsilciler, kendilerini seçen mevcut vatandaşları değil geçmişte yaşamış ve gelecekte yaşayacak olanları da kapsayacak bir şekilde bütün milleti temsil etmektedir ${ }^{81}$. Fransız devriminde de önemli bir etkiye sahip olan milli egemenlik teorisi, teokratik egemenlik teorilerinin yerine beşeri bir egemenliği getirmiştir. Fakat burada egemenliği kullananlar ya da temsilciler, somut insanları aşan soyut bir millet kişiliğini temsil etmektedir. Bu nedenle milli egemenlik

Eroğlu (n 74) 139.

76 Sarıca, Siyasi Düşünce (n 12) 156.

77 ibid 153.

78 Sieyes, aslında genel oy ilkesini bile kabul etmeyen ve burjuva dışındaki proleteryanın mümkün olduğunca yönetim dışında kalmasını isteyen bir düşünürdür. Millet gibi soyut bir kavramı ortaya atarak ve aktif-pasif vatandaş ayrımı gibi ayrımlara giderek sadece burjuvazinin hükümranlık süreceği bir anayasal düzen kurmak istemektedir. Öyle ki belirli bir mülkiyete sahip olmayan ya da belirli bir vergi vermeyen vatandaşları pasif vatandaş statüsüne sokmakta ve onlara oy hakkı verilmemesini istemektedir. Kısacası Sieyes, sadece burjuvazinin temsil edildiği ve bu burjuva düzeninin hukukileştirilerek meşrulaştırıldığı bir anayasa ve devlet istemektedir. ibid 159; Yine benzer şekilde Rousseau'nun mutlak demokrasisine karşı olan Constant da modern vatandaşın özgürlüklerinin korunmasından bahsederek tam bir anayasacılık fikri ileri sürmektedir. Constant, bireyin halk egemenliği adına bile sınırlanamayan bir yanı olduğundan bahsetmektedir. Fakat burada da asıl dert, yine burjuvazinin çıkarlarını korumaktır. Zira aynı şekilde kitlelerin etkisini azaltmak amacıyla sınırlı oy ilkesi gibi ilkeler benimsenmektedir Constant'ın düşüncesinde. ibid 168.

79 ibid 160.

$80 \quad$ Eroğlu (n 74) 138.

81 "Milli hakimiyet telakkisine göre hakimiyet millete aittir. Millet de bir şahıstır, bir hükmi şahıstır. Hakimiyet, mahiyetinden hiçbir şey kaybetmeksizin evvelce hükümdara yani tek bir şahsa ait iken, ondan alınmış ve millet dediğimiz topluluğa, millet hükmi şahsına tevdi edilmiştir. Yani evvelce hakimiyet şahsi iken anonim bir hale sokulmuş ve fakat mutklak karakterinden hiçbir şey kaybetmemiştir. Böylece milli hakimiyet teorisi hakimiyetin sadece sahibini değiştirmiş bulunmaktadır." Özçelik (n 5) 63. 
ile halk oylaması, halk vetosu ve halk teşebbüsü gibi yarı doğrudan demokrasi araçları bağdaşmaz. ${ }^{82}$ Yani temsilci, bir defa seçildikten sonra artık soyut bir kişilik olan millet adına hareket etmeye başladığı için milli egemenlik, emredici vekâlet ve temsilcilerin azli gibi usullerle bağdaşmaz. ${ }^{83}$ Bir nevi seçmenlerin sadece millet soyut kişiliğini temsil edecek kişileri yine kendilerinden ayrı ve üstün bir varlık olan millet adına seçtikleri söylenebilir. Seçmenler, milleti temsil edecek temsilcileri belirleme görevine sahiptir ama o temsilciler üzerinde emir ve talimatta bulunma yetkisine sahip değildir. Milli egemenliğe göre seçmenlik bir hak değil görevdir ve zorunlu oy ilkesi bu teori ile bağdaşmaktadır. ${ }^{84}$ Seçmenler, milleti temsil edecek temsilcileri belirleme görevine sahiptir ama o temsilcilere emir ve talimat verme yetkisine sahip değildir. Bazı zorlamalarla seçmenlerin oy verme konusunda zorunluluğa tabi tutulması milli egemenlik ilkesinin bir sonucu olarak karşımıza çıkmaktadır. Bu gibi özellikleri bakımından milli egemenliğin soyut ve şekilci bir demokrasi anlayışına yol açtı̆̆ 1 söylenebilir. ${ }^{85}$ Ancak teori kendi içinde tutarlılığa sahiptir. Hatta sınırlı oy ilkesi gibi günümüz demokrasi anlayışıyla uyuşmayacak bazı özellikler de milli egemenlik teorisiyle bağdaşmaktadır. Milletin iradesini açılamaya en yetenekli olan kişileri seçmek için oy verme görevi herkese değil sadece bu görevi layıkıyla yerine getirebilecek kişilere verilmelidir. ${ }^{86}$

Millet, mevcut yaşayan bireylerden farklı bir soyut kişilik olduğu için çoğunluğun frenlenmesi milli egemenlik ilkesinin bir gereği olarak düşünülebilir. Bu bakımdan çift meclislilik, kuvvetler ayrıllğ 1 ve anayasa mahkemesinin varlığ teorisi yaklaşımıla bağdaşır niteliktedir. ${ }^{87}$ Zaten çift meclislilik, yasama organını kendi içinde sınırlandırmayı ve kuvvetler ayrılığı da egemenliği kullanan yasamayürütme-yargı organlarını birbirine karşı sınırlandırmayı amaçlamaktadır. Anayasa mahkemesi ise birey hak ve hürriyetlerinin iktidar karşısında korunmasını sağlamaktadır. ${ }^{88}$

\footnotetext{
Gözler, Anayasa Genel Teori (n 18) 444.

ibid 444.

$\operatorname{ibid} 443$.

Eroğlu (n 74) 139.

Gözler, Anayasa Genel Teori (n 18) 444.

87 ibid 444; Ancak bazı anayasalarda milli egemenlik teorisinden etkilenerek anayasanın üstünlüğü kabul edilmiș olsa da bunu denetleyecek etkin bir mekanizma kabul edilmemektedir. Örneğin; Hollanda'da yazılı bir anayasa mevcut olmasına rağmen kanunların anayasaya uygunluğunun denetlenmesinin açıç̣a yasaklandığı görülmektedir. Bu durumda yasama organı, kendi çıkardığı kanunların anayasaya uygun olup olmadığını kendi denetlemektedir. Sonuç olarak yürürlükteki bütün kanunlar, yasama organının yorumuna göre anayasaya uygundur. Zira bu kanunlar anayasaya aykırı olsaydı yasama organı onları kabul etmeyecekti. ibid 358; Benzer şekilde 1924 Türkiye Cumhuriyeti anayasası her ne kadar kanunların anayasaya aykırı olamayacağını kabul etmiş olsa da bu durumu denetleyecek herhangi bir mekanizmaya yer vermediğinden çoğunluk iradesini sınırlandırmamaktadır. Bu anlamda 1924 anayasası çoğulcu değil çoğunlukçu bir anayasadır. Zaten 1924 anayasasının çoğunlukçu demokrasi anlayışını benimseyerek azınlıkta kalanların haklarını güvence altına almaktan uzak olduğu sıkça ifade edilmektedir. Mehmet Akad, Bihterin Vural Dinçkol, Nihat Bulut, Genel Kamu Hukuku, (16. Bası, Der Yayınları 2020) 395.

88 Anayasa mahkemesi, çoğulcu demokrasinin, sınırlı iktidarın ve insan haklarının çoğunlukçu demokrasi anlayışına karşı korunmasının bir sonucudur. Yavuz Atar, Türk Anayasa Hukuku (13. Bası, Seçkin Yayınları 2020) 328.
} 


\section{Milli Egemenlik Teorisinin Tarihsel Olarak Anayasacılıkla İlişsisi}

Anayasacılık kuvvetler ayrılığı ve anayasa mahkemesi ile iktidarı sınırlandırmak istemektedir. Milli egemenlik teorisi, halk egemenliği teorisinin aksine bu özelliklerle bağdaşır niteliktedir. Hatta kanaatimizce anayasacılık bir bakıma da soyut bir varlık olan milletin bu soyutluğundan kaynaklanmaktadır. Zira milli egemenlik teorisi "millet sadece somut olarak yaşayan bireylerin toplamından ibaret değil, geçmiş ve geleceği de kapsar" diyerek çoğunluğunun iradesini sınırlandırmanın önünü açmaktadır. Milli egemenlik, tarihsel açıdan da Fransız Devrimi sonrasında bir yandan kralın mutlak iktidarı yıkılırken diğer yandan mutlak iktidarın halkın eline geçmesini engelleyen bir formül olma görevini ifa etmiştir ${ }^{89}$.

Tarihsel olarak incelendiğinde de milli egemenlik teorisi, -her ne kadar zamanla anlamı nispeten değişmiş olsa da- burjuvazi düşüncesi olarak ortaya çıkmış ve anayasa yapım süreçleri de bu sınıfın (burjuvazinin) kurumsallaşması olarak gelişmiştir. Fransız devrimi burjuva sınıfı öncülüğünde yapılmış, sonrasında ise (Robespierre ve Babeuf gibi radikal devrimcilere rağmen) burjuvazinin iktidarı ele geçirmesiyle sonuçlanmıştır. ${ }^{90}$ Fransız devriminin öncülüğünü yapanlara göre ortak aklın buyruklarını bulmak herkesin yapabileceği bir iş değildir. ${ }^{91}$ Sieyes de görüşlerinde aktif-pasif vatandaş ayrımına gitmektedir, devrim sonrası meclisler de çoğunlukla burjuva kökenli temsilcilerden oluşmaktadır. İlk zamanlarda seçimler bile sadece belirli bir mülkiyete ve özelliklere sahip burjuvalara hak olarak tanınmaktadır. $\mathrm{Bu}$ bakımdan egemenliğin millete ait olduğu kurgusu üzerine temellendirilmiş olan milli egemenlik teorisi, ilk zamanlarda aristokratların ayrıcalıklarından kurtulan burjuva sınıfının kendi iktidarlarını sağlama alma ve yeni bir meşru otorite kurma çabasının ürünü gibi hizmet etmiştir. ${ }^{92}$ Kanaatimizce anayasacılığg, bir diğer taraftan okursak, burjuva sınıfını başta mülkiyet olmak üzere kendi ayrıcalıklarını koruma altına alma amacı olarak düşünebiliriz. Örneğin 1791 Fransız anayasası açıkça aktif-pasif yurttaş ayrımı yapmakta ve aktif yurttaşlar olarak burjuva sınıfını saymaktadır. ${ }^{93}$ Böylece burjuvazi, mülkiyet ve vergi verme ayrımı ile belirlenen aktif yurttaşlık sayesinde Tiers Etat içindeki müttefiklerinden ayrışmakta ve kendi üstünlüğünü kurumsallaştırmaktadır. ${ }^{94}$

\footnotetext{
89 Teziç (n 60) 101.

90 "Geniş halk yığınlarını peşinden sürüklemek için demokratik ilkeleri bayraklaştıran burjuvazi, zaferden sonra ziyafet sofrasına tek başına oturur. 1789 yeni bir aristokrasi türetmiştir, illi emlak alım satımıyla zenginleşen köksüz ve hayasız bir para aristokrasisi." Cemil Meriç, Saint- Simon: İlk Sosyolog, İlk Sosyalist (21. Bası, İletişim Yayınları 2019) 38; “Aslında artık bir azınlık halkın çoğunluğunu yönetirken bazı inandırmalar üzerine hüküm sürmektedir. Temsilcilerin milletin sesi olduğuna inandırmak, hükümetin halkın hizmetkarı olduğuna inandırmak..." Morgan (n 62) 13.

91 Murat Sarıca, 100 Soruda Fransız Ihtilali (Gerçek Yayınevi 1981) 48.

92 "Modern zamanların siyasal örgütlenme modeli olarak liberal ulus devletin, egemenliğin ulusa ait olduğu kurgusu üzerine temellendiğini ama gerçekte sanayi devrimi sonrasında yükselen burjuva sınıfının, aristokratlar lehine düzenlenmiş feodal orta çağ toplumsal yapısıyla kanlı bir hesaplaşmasının ürünüdür." Aslan Delice, 'Bürokrasi: Monarşiden Cumhuriyete Değişmeyen İktidar' (2014) (17) Türkiye Adalet Akademisi Dergisi 41, 42.

93 Yavuz Yıldırım, 'Fransız Devrimi'nde Yurttaşlık ve Etkilerine Dair Bir Değerlendirme' (2019) 21 (Ek Sayı) Trakya Üniversitesi Sosyal Bilimler Dergisi 251, 260.

94 Server Tanilli, Dünyayı Değiştiren On Yll: Fransız Devrimi Üstüne (Sayı Yayınları 1989) 88; Aktaran: Yıldırım (n 92) 261.
} 
Sonuç olarak; milli egemenlik teorisi ve anayasacılık, her ikisi de, tarihsel olarak burjuvazinin bir düşüncesi olarak ortaya çıkmıştır. Eski kralın mutlak iktidarına karşı bir araç olarak kullanılan "milli egemenlik", mutlak iktidarın halka geçmesinin önündeki en büyük engel olma görevini de ifa etmektedir. Bu açıdan bakıldığında bir tarafta monarşideki mutlak iktidar diğer tarafta da halkın mutlak iktidarı mevcuttur. Milli egemenlik teorisi ise soyut bir "millet"e dayandırdığ 1 egemenlik düşüncesiyle hem kralın mutlak iktidarını yıkmakta hem de çoğunluğun mutlak iktidara sahip olmasını engellemektedir. Kısacası milli egemenlik, burjuvazinin istediği "sınırlı" iktidarın formülüdür. Anayasacılık da sınırlı iktidarı amaçlamakta olduğundan, kanaatimizce, milli egemenlikle sıkı ilişki içindedir. Günümüzde bazı değişikliklere uğramış olsalar da kazandıkları yeni anlamlar bakımından bu iki kavram birbiriyle sıkı ilişkisini sürdürmektedir.

\section{4. İlk Anayasayı Yapan Devlet Amerika Birleşik Devletleri ve Yazılı Bir Anayasaya Sahip Olmayan Devlet İngiltere}

Dünya üzerindeki ilk anayasanın 1787 Amerika Birleşik Devletleri anayasası olduğu kabul edilmektedir. ${ }^{95}$ ABD anayasasının dünya genelinde tarihsel bir etkiye sahip model anayasa olduğu açıktır. ${ }^{96}$ İngiltere'nin koymuş olduğu ağır vergilere karşı isyan eden Amerika'daki on üç koloninin İngiliz hükümetine karşı başlattığı bağımsızlık mücadelesi bu anayasayla sonuçlanmıştır. İngiltere'den ayrılıklarını resmen Amerikan Bağımsızlık Bildirgesiyle ilan eden koloniler, federal bir devlet kurma yoluna gitmiştir. Böylece 1787 yılında dünyanın ilk yazılı anayasası olan Amerika Birleşik Devletleri anayasası kaleme alınmıştır. ${ }^{97}$ Anayasa, başlangıç metninde saymış olduğu refahı ve özgürlüğü "kendimize ve gelecek kuşaklarımıza temin etmek amacıyla bu Amerika Birleşik Devletleri Anayasası'nı takdir ediyor ve yapıyoruz"98 demektedir. Bu anayasa, milli egemenlik teorisinin sunmuş olduğu ve gelecek kuşakları da kapsayan soyut bir millet varlığının refah ve özgürlüğünü sağlayacak hakları güvence altına almak istemektedir. Ayrıca 1787 ABD anayasası, bir bakıma popülizme karşı bir saldırıdır. ${ }^{99} 1787$ tarihli Amerika Birleşik Devletleri

\footnotetext{
95 Kaboğlu (n 3) 2.

96 Fakat her ne kadar geçmişte ABD anayasasının önemli etkileri olmuş olsa da günümüzde bu etkinin giderek azaldığ iddia edilmektedir. Bkz. Mila Versteeg, Emily Zackin, ‘American Constitutional Exceptionalism Revisited' (2014) 81 (4) University of Chicago Law Review 1641, $1642<$ https://www.jstor.org/stable/43151587> Erişim Tarihi 31.12.2020.

97 Ancak Amerika Birleşik Devletleri Anayasası ilk yazılı anayasa olmasına rağmen yazılı olmayan anayasanın karakteristik özelliklerini de taşımaktadır. Pu Zengyuan, 'A Comparative Perspective on the United States and Chinese Constitutions' (1989) 30 (4) William and Mary Law Review 867, 873 <https://scholarship.law.wm.edu/cgi/viewcontent. cgi?article=2021\&context=wmlr $>$ Erişim Tarihi 15.12.2020.

98 Preamble, Constitution of United States of America, constituteproject.org/constitution/United_States_of_America_1992 Erişim tarihi 15.12.2020.

99 Hideaki Shinoda, 'Conflicting Notions of National and Constitutional Sovereignty in the Discourses of Political Theory and International Relations: A Genealogical Perspective' (Doktora Tezi, London School of Economics and Political Science 1998) $57<$ https://core.ac.uk/download/pdf/46519243.pdf> Erişim Tarihi 20.12.2020.
} 
anayasası, bir bakıma Federal ABD'nin de kurucu belgesi niteliğindedir. ${ }^{100}$ Federalizm içindeki küçük olan ya da azınlıkta kalan federe devletlerin haklarını güvenceye alan ABD anayasası, bu yönüyle de açık bir şekilde çoğunluk iradesini sınırlandırmayı amaçlamaktadır. Kanaatimizce bu ilk anayasa, açık bir şekilde halk egemenliği teorisinden uzaktır. Her ne kadar bu anayasa "biz, Birleşik Devletler halkı" diye başlasa da kurucu referandumla yapılmamıştır. İlk anayasa olarak kabul edilen 1787 ABD anayasasının bu konudaki önemli bir özelliği, tüm birleşik devletler halkı tarafından yapılmamış, sınırlı bir grup tarafından kaleme alınmış olmasıdır. ${ }^{101} \mathrm{Bu}$ da ilk anayasanın yapımında milli egemenlik teorisine dayanan kurucu meclis usulünün kullanılmış olduğu anlamına gelmektedir.

Sonuç olarak; ilk anayasa olan 1787 ABD anayasası, federal bir devlet kurmak amacıyla bir araya gelen ve çoğunluğa karşı kendi federe devletlerini güvence altına almayı amaçlayan bir belgedir. Bu bakımdan ilk anayasa, hem egemenliğin kullanılmasında iktidarı federe ve federal düzeyde paylaştırarak sınırlandırmakta hem de azınlıkları çoğunluğa karşı, popülizme karşı korumaktadır. Aslında anayasacılığın amacına baktığımızda da aynı şekilde iktidarı sınırlandırmayı ve bireylerin temel hak ve hürriyetlerini güvenceye almayı görmekteyiz. Bütün bunlar, milli egemenlik teorisinin soyut millet anlayışıly uyum içinde görünmektedir. Halk egemenliği teorisindeki çoğunluğun iktidarına karşılık belki şu anda yaşamayan ama gelecekte yaşayacak olan farklı düşüncelerin bile millet soyut kişiliği içinde düşünülerek şimdiden korumaya alınmasını amaçlayan düşünce anayasacılıkla oldukça ilişkili görünmektedir.

İngiltere'de anayasal devletin özellikleri bulunmakta ancak yazılı bir anayasa bulunmamaktadır. ${ }^{102}$ Anayasacilık iktidarı sınırlandırmak ve bireylerin temel hak ve hürriyetlerini güvence altına almak ise bunu en iyi başaran devletlerden birinin İngiltere olduğu açıktır. İngiltere, parlamentonun ilk ortaya çıktığı ülke olarak da demokrasi açısından büyük önem taşımaktadır. Ancak İngiltere'de parlamento, Kral, Lordlar ve Avam arasında bölüştürülmüş bir egemenliği temsil etmekteydi. ${ }^{103}$ Tarihsel süreçte İngiltere'de hep bir iktidarın sınırlandırılması fikri pratiğe yansımıştır. Milli egemenlik teorisi bakımından bir değerlendirmede bulunulacak olursa milletin soyut bir varlık olması, iktidarın hep sınırlandırılmasını gerektirmektedir denilebilir. Hatta günümüzde İngiltere'de kraliçenin hala varlığını sürdürmesi, kanaatimizce kraliçenin millet soyut kişiliğini oluşturan geçmişin temsilcisi olarak var olmaya

\footnotetext{
100 Amerika Hakkında: Amerika Birleşik Devletleri Anayasasl, https://photos.state.gov/libraries/turkey/231771/PDFs/abdanayasasi.pdf Erişim tarihi 16.12.2020.

101 Charles Austin Beard, An Economic Interpretation of the Constitution of the United States (Simon Schuster 1986) 325.

102 Buna karşılık Sartori, İngiltere’yi yazısız anayasaya sahip bir devlet olarak görmemektedir. Sartori’ye göre tek bir en üst hukuk belgesinde bu kuralların toplanmamış olması İngiltere'nin yazısız anayasaya sahip olduğu anlamına gelmemektedir. Sartori, İngiltere'nin sistemleştirilmiş bir anayasaya sahip olmadığını söylemeyi tercih etmektedir. Ona göre İngiltere'nin parça parça ve kısmen yazılmış, çeşitli kaynaklara dağılmış bir anayasası vardır. Sartori (n 4) 855.

103 ibid 853.
} 
devam ettiği şeklinde yorumlanabilir. ${ }^{104}$ Çoğunluk iradesinin çıkarmış olduğu bir kanunun sembolik de olsa kraliçenin onayından geçmesi, milli egemenlik teorisi çerçevesinde millet soyut kişiliğinin geçmişi de kapsadığ 1 düşüncesi açısından değerlendirilebilir. Sonuç olarak anayasacılık, günümüz demokrasilerinde artık kanaatimizce çoğunluğun iktidarını sınırlandırmak anlamına gelmektedir. $\mathrm{Bu}$ bakımdan ilk anayasayı yapan ABD de şimdi incelenen İngiltere de anayasacılık düşüncesini barındıran ve çoğunluk iktidarını sınırlandırıp bireylerin temel hak ve hürriyetlerini güvence altına alan devletlerdir.

\section{Milli Egemenlik Teorisine Dayanan Devlet Modeli: Anayasal Devlet}

Anayasacılık, geçmişivegeleceğidekapsayanbirşekildeiktidarısınırlandırmaktadır. Kanaatimizce anayasacılık, anayasanın yapıldığı anda o devlette belirli bir görüsşte bir bireyin bile bulunmaması durumunda bile gelecek bir zaman diliminde o görüşte birileri olabilir düşüncesini içinde barındırır. Böyle yorumlandığında, anayasacılığın bariz bir şekilde milli egemenlik teorisi temeli üzerinde yükseldiği görülmektedir. Halk egemenliği teorisine göre belirli bir anda yaşayan halk egemenliğin kaynağını oluşturmaktadır. Fakat anayasacılık, kanaatimizce belirli bir anda yaşayan halkın hiçbirisinin benimsemediği bir insanın bile temel haklarını, böyle bir insanın gelecekte bir gün o devlette yaşayabileceğinden bahisle, bu halkın tamamına karşı güvenceye alınmasını amaçlamalıdır. Soyut bir millet kavramına dayanan egemenlik teorisi, geçmişi ve geleceği kapsayacak bir şekilde iktidarı sınırlandırmayı ve bireylerin haklarını güvenceye almayı amaçlayan anayasacılıkla uyum içindedir. Anayasal devlet modeli, kanaatimizce milli egemenlik teorisiyle ilişkilidir.

\section{B. Halk Egemenliği}

Halk egemenliğine göre egemenlik, milli egemenlik anlayışından farklı bir şekilde yaşayan kişilerin her birine aittir. Dolayısıyla egemenlik, kişilerin her birinin birer payına bölünmüş durumdadır ve bu payların toplamı anlamına gelmektedir. ${ }^{105}$ Halk egemenliği, kaynağını Rousseau'da bulmaktadır. Halk egemenliği, kaynağını Rousseau'nun Toplum Sözleşmesi eserinde bulmaktadır. ${ }^{106}$

\section{Rousseau'nun Görüșleri ve Halk Kavramı}

Rousseau'nun toplum sözleşmesi düşüncesi, özellikle de egemenliğin devredilmezliği ve bölünmezliği fikri halk egemenliği teorisinin kökenini oluşturmaktadır. Rousseau'ya göre halk hem egemenliğin kaynağ 1 hem de onun

\footnotetext{
104 Kraliçenin, geleneği ve geçmişi yansıtan bir konumda olduğu düşünülürse aslında sembolik olarak varlığını sürdürmesinin bir sonucu da milleti oluşturan geçmişi temsil etmesidir diyebiliriz.

105 Kubalı (n 73) 202.

106 Özçelik (n 5) 64; Tarhan (n 72) 5.
} 
kullananıdır. Bu düşünce halk egemenliğinin doğuşunu oluşturmaktadır. ${ }^{107}$ Dolayısıyla dikkat edilecek olursa Rousseau'nun görüşlerinden hareketle egemenin somut olarak halkı meydana getiren kişilerin toplamı olduğu görülmektedir. ${ }^{108}$ Görüldüğü üzere halk kavramı, millet kavramından farklı olarak soyut değil somut bireylerin toplamını ifade etmektedir. Dolayısıyla halk egemenliği teorisi, somut bireylerin çoğunluğuna dayanan genel iradenin en üstün iktidar olduğunu iddia etmektedir. Zaten halk egemenliğinin teorisyeni Rousseau da genel iradenin ortak değerlerin yansıması olduğu için sınırlandırılamayacağını söylemektedir. ${ }^{109}$

\section{Halk Egemenliği Teorisinin Genel Özellikleri}

Halk egemenliği, ilk olarak temsili demokrasiyle bağdaşmayı doğrudan ve yarı doğrudan demokrasi sistemlerini gerektirmektedir. ${ }^{110} \mathrm{Bu}$ teoriye göre aslında egemenlik doğrudan halk tarafindan kullanılan bir şey olduğu için devir, ferağ ve temsil edilemez. ${ }^{111} \mathrm{Bu}$ bakımdan halk egemenliği teorisi, özünde, doğrudan demokrasiyle bağdaşır bir teori olarak karşımıza çıkmaktadır. Ancak günümüz geniş devletlerinde ve yüksek nüfus oranları düşünüldüğünde doğrudan demokrasinin uygulanması imkânsız görünmektedir. Temsili demokrasinin milli egemenliğin aksine teorik olarak halk egemenliği için bir zorunluluk olmadığı aşikardır. Ancak

107 Küçük (n 70) 336.

108 “Halk Hakimiyeti nazariyesi kaynağını J. J. Rousseau’nun "İçtimai Mukavele” eserinde bulur. Orada bir pasajda Rousseau hükümran (siyasi hey’etin) kendisini teşkil eden, meydana getiren fertlerin yekunundan ibaret olduğunu şu şekilde beyan etmektedir. "Bir devletin 10.000 vatandaştan meydana geldiğini farzedelim. Bu halde devletin her üyesi (vatandaş, teb'a) nin devletin üstün otoritesinde (hakimiyet hakkında) 1/10.000 nisbetinde bir hissesi (şâyi hakkı) vardır.” Özçelik (n 5) 64.

109 Atilla Yayla, 'Anayasacılık, Anayasal Demokrasi ve İdeolojiler' (2012) (66) Liberal Düşünce 13, 17; Aslında Rousseau tam anlamıyla eşitliği benimsemektedir. Ancak John Stuart Mill gibi demokratik liberalizmin savunucularının belirttiği üzere bu durum, çoğunluk tiranlığına dönüşebilecektir. Dolayısıyla iktidarın sınırlandırılması bir yana, tam aksine çoğunluk iradesinde vücut bulan iktidarın tam anlamıyla sınırsız bir tiranlık olacağı görülmektedir. Tocqueville bu durumu şu şekilde eleştirmektedir: "Her şeyi yapabilme gücümü nasıl kendi eşitim birine vermeyi reddediyorsam, bu gücü bir grup insana da veremem.” Bihterin Dinçkol, 'Çoğunluk Tiranisine Karşı Bir Çözüm Yolu: Tocqueville'nin Siyasal Kuramı' (2004) 3 (5) Istanbul Ticaret Üniversitesi Dergisi 149, 154; Aslında Tocqueville, Rousseau'nun genel iradesini bir devlette yaşayan halkın iradesinden ziyade tüm insanlığın genel iradesi olarak genişletmektedir. Bir grup insana -ki bunlar o devletteki halkın çoğunluğu olsalar bile- buyurma yetkisini vermemesini, aslında tüm insanlığın çoğunluğunun iradesine başvurarak açıklamaktadır. Tocqueville, halkın çoğunluğunun buyurma hakkını yadsırken aslında halkın egemenliğine değil insanlığın egemenliğine başvurmaktadır. Alexis de Tocqueville, Çoğunluğun Zorbalı̆̆ (İnci Malak Uysal çev, Can Yayınları 2020) 47; Tocqueville, eşitlik isteğinin insanın doğasından kaynaklı ahlaki bir istek olduğunu düşünüyordu. Ancak Rousseau'nun genel irade yanılmaz ve çoğunluğa katılmayan azınlık için bile iyi olan kararı verir düşüncesinin aksine Tocqueville, ileri götürülmüş bir eşitliğin özgürlüğü tehdit edeceğini ve çoğunluğun tiranlığına dönüşeceğini düşünüyordu. Sanford Lakoff, 'Liberty, Equality, Democracy: Tocqueville's Response to Rousseau' in George Feaver, Frederick Rosen (edr), Lives, Liberties and the Public Good: New Essays in Political Theory for Maurice Cranston (Palgrave Macmillan, 1987) 101; Kanaatimizce Rousseau, düşüncesinde çok somut bir şekilde çoğunluğu oluşturan insanların sınırlandırılamayan iktidarına yer vermiş olmasına rağmen bu sınırsız iktidar fikrini kendi de mantıklı bulmamaktadır. Bu nedenle Rouesseau, genel iradenin yanılmazlığına, genel iradenin aslında somut bir toplamdan ibaret olmadığına ve azınlıkta kalanların aslında sadece genel irade denilen bu soyut iradeyi tespitte yanıldığına vurgu yapma gereği görmektedir. Fakat bu durum kanaatimizce içinde bir çelişki barındırmaktadır. Öyle ki milli egemenlik teorisinin soyut millet kavramının karşısına somut bir şekilde tek tek bireylerin toplamını oluşturan halk kavramını koyan Rousseau, genel iradenin bireylerin iradelerinin toplamı olmadığını aksine topluluğun bir iradesi olduğunu söyleyerek büyük bir çelişki içine düşmektedir. Bu çelişki, kanaatimizce Rousseau'nun aslında içten içe salt sayısal çoğunluğa sahip oldu diye bir somut iktidarın sınırsız olmasını kabul etmediğinden kaynaklanmaktadır. Dolayısıyla Rousseau, genel iradeyi ayrı bir soyut irade gibi düşünerek meşrulaştırmak istemektedir. Fakat sonuçta halk egemenliği teorisi, çoğunluğun iradesinin sınırlandırılmasına uzak bir teoridir. Kısacası Rousseau'nun fikirleri ve halk egemenliği teorisi, iktidarı sınırlandırmayı amaçlayan anayasacılıkla bağdaşmamaktadır.

110 Gözler, Anayasa Genel Teori (n 18) 446.

111 Özçelik (n 5) 65. 
günümüz koşulları göz önünde bulundurulduğunda halk egemenliği ile temsilcilerin halk tarafından yönlendirildiği ve doğrudan demokrasi araçlarının kullanıldığı bir temsil sistemi bağdaşabilir. Aslında buna temsil sistemi demek de doğru olmayacaktır. Halk egemenliği teorisine göre temsilciler ya da milletvekilleri, gerçek anlamda kendilerini seçen halkın temsilcileri değildir. Rousseau'ya da göre temsilciler halkı temsil eden kişiler değil de olsa olsa geçici görevliler olabilir, hiçbir kesin karara kendi başlarına varamazlar. ${ }^{112}$ Burada kanaatimizce yüksek nüfustan kaynaklı olarak zorunlu bir milletvekilliği sisteminin kabulü söz konusudur. Milletvekili ya da temsilcilerin ise her an halk tarafından emir ve talimatlarla yönlendirilebilecek ve istenildiğinde görevden alınabilecek kişiler olması gerekmektedir. ${ }^{113}$ Ayrıca halkın her zaman doğrudan yönetime katılması da bu teoriyle bağdaşır bir özellik olacaktır. Dolayısıyla halk oylaması, halk teşebbüsü, halk vetosu gibi yarı doğrudan demokrasi araçları bu teoriyle bağdaşmaktadır. ${ }^{114}$ Halk egemenliğinde millet egemenliğinin aksine seçmenlik bir hak olarak karşımıza çıkmaktadır, ihtiyari oy bu teorinin bir sonucudur ve bu teori için sınırlı oy ilkesi değil genel oy ilkesi geçerlidir. ${ }^{115}$ Günümüz demokrasileri açısından düşünüldüğünde reşit olmuş her kadın ve erkeğin hiçbir sınırlama olmaksızın ve vergi verme ya da belli miktar mülkiyete sahip olma gibi şartlar aranmaksızın seçmen olması, halk egemenliği teorisinin sonucudur. Son olarak halk egemenliği, bir bütün olarak egemenin halk olduğunu kabul ettiği için kuvvetler ayrılığı ilkesiyle, iki meclislilikle ve anayasa mahkemesi gibi organların varlığıyla bağdaşmaz. ${ }^{116}$

Sonuç olarak hem milli egemenliğin hem de halk egemenliğinin temel özelliklerinde bir karşıtlık göze çarpmaktadır. Bu ayrımın temel sebebi de bir teorinin egemenliği soyut bir kişilik olarak millete diğer teorinin ise somut bireylerin toplamı olarak halka dayandırmasından kaynaklanmaktadır.

\section{Halk Egemenliğine Dayanan Devlet Modeli: Anayasalı Devlet}

Anayasacılık, daha önce de ifade edildiği gibi, geçmişi ve geleceği kapsayan bir millet kavramı üzerine şekillenerek ortaya çıkmış olduğu için belirli bir anda yaşayan halkın iradesini sınırlandırmaktadır. Gerçek anlamda bir anayasal devlette belirli bir andaki halkın çoğunluğunun iradesi anayasa mahkemesi gibi mekanizmalarla denetlenmektedir ve zaten kuvvetler ayrılığı gibi iktidarın dengelenmesi mekanizmalarıyla sınırlandırılmış bir vaziyettedir. Dolayısıyla bu bakımdan anayasayı yapan kurucu iktidar, millet adına hareket ederek bugünü ve geleceği

\footnotetext{
12 Gözler, Anayasa Genel Teori (n 18) 446.

113 "Dolayısıyla bu teori, emredici vekalet sistemini gerektirir. Yani bu teoride egemenlik halka ait olduğuna göre halkın temsilcileri halkın emirleriyle bağlıdır ve bu emirleri yerine getirmek zorundadırlar. Halk verdiği emirleri yerine getirmeyen temsilcileri görevden alabilir. Yani temsilcilerin azli usulü halk egemenliği teorisiyle uyuşum içindedir.” ibid 446.

114 ibid 446.

115 ibid 445

116 ibid 446.
} 
bağlayan kararlar almaktadır ve böylece bir bakıma halkı, doğrudan demokratik işleyiş sürecinde bulunmaktan uzaklaştırmaktadır. ${ }^{117}$ Egemenlik teorileri bakımından incelendiği zaman, aslında bariz bir şekilde böyle bir sonucun halk egemenliği teorisiyle uyuşamayacağı görülecektir. Sonuçta halk egemenliği teorisi temelinde inşa edilen bir devlet teşkilatlanması, her zaman belirli bir anda yaşayan insanlardan oluşan halkın demokratik iradesini öncelemek isteyecektir. Böyle bir düşünce temelinde ise bir anayasa metninin var olması sembolik olacaktır. Halk egemenliği teorisine dayanan bir devlet modelinde anayasa metninin var olması o devleti anayasal devlet yapmayacaktır. Zira anayasal devlet, günümüz demokrasilerinde artık halkın çoğunluğunun iktidarını sınırlandıran bir devlet modeli olarak yorumlanmalıdır.

Halkın çoğunluğunun iradesini en üstün tutmayı amaçlayan bir devlet modeli, bu iradeyi sınırlandırmayı amaçlayan bir anayasayı en üstün tutmak isteyen bir devlet modelinden uzak görünmektedir. Gerçekten içerik olarak anayasa denilebilecek bir belge hazırlanıp kabul edilmiş olsa bile bu devlet modelinde halkın demokratik iradesi daha üstün tutulacaktır. Örneğin anayasal denetim yasaklanacak, kanunların anayasaya aykırıllğı gerekçesiyle iptali mümkün olmayacak, her konuda son sözü halkın çoğunluğunun söylemesi gerektiği gibi popülist söylemler dile getirilecektir. Hatta anayasacılığın temel amaçları olan iktidarın sınırlandırılması ve bireylerin haklarının güvenceye alınması gibi özelliklerin bile halkın çoğunluğu tarafından değiştirilebileceği ve bunun demokratik olarak meşru olduğu savunulacaktır.

Halk egemenliği teorisinin demokrasi anlamında daha değerli olduğu savunulabilse bile anayasal devlet modeli bakımından savunulamaz olduğu açıktır. Halk egemenliği teorisine dayanılarak bir anayasanın yapılması, anayasacıllğın amaçlarının benimsendiği anlamına gelmeyecektir.

\section{Halk Egemenliği Teorisine Dayanan Kurucu Referandumun Halkın İradesini Sınırlandırması Çelişkisi}

Kanaatimizce anayasanın yapım süreçleri milli egemenlik teorisine daha uygundur. Anayasacılığın amacının iktidarı sınırlandırmak olduğunu ve anayasaların iktidarı sınırlandırmak için yapıldığını düşündüğümüz zaman demokratik ülkelerde o iktidarın aslında halkın yansıması olduğunu da göz önünde bulundurmalıyız. Hatta daha da ileri giderek anayasanın halkı sınırlandırdığını iddia edebiliriz. Yani anayasacılık belirli bir zaman diliminde karar alma çoğunluğuna sahip bireyleri sinırlandırmayı amaçlamaktadır ve anayasalar bu nedenle yapılmaktadır. $\mathrm{Bu}$ bakımdan halk egemenliği teorisine dayanan kurucu referandum ile halkın iradesini sınırlandıran bir anayasanın yapılması, kendi içinde bir çelişki barındırmaktadır.

117 Mithat Sancar, 'Anayasal Demokrasi: Demokrasinin Sınırı mı, Güvencesi mi?' in Ozan Ergül (ed), Demokrasi ve Yargl (Türkiye Barolar Birliği Yayınları 2005) 45. 
Kurucu referandum, kurucu iktidarın anayasa yapım sürecindeki bir usulüdür. Öncelikle kurucu iktidar kavramına bakacak olursak kurucu iktidar, devleti ve anayasayı kuran güçtür diyebiliriz. ${ }^{118}$ Dolayısıyla burada sıfırdan ve ilk elden kuran-yapan ya da mevcut bir sistem içinde yeniden kuran-değiştiren bir güç söz konusudur. Kısaca kurucu iktidar, anayasayı yapma ve değiştirme iktidarı olarak tanımlanabilir. ${ }^{119}$ Anayasaların ilk elden yapılması gücü, asli kurucu iktidar olarak ve sonrasında mevcut anayasal sistem içerisinde o anayasaların değiştirilmesi gücü de tali kurucu iktidar olarak karşımıza çıkmaktadır. ${ }^{120}$ Yani asli kurucu iktidar, sıfırdan ve ilk elden anayasa yapma gücüne sahip olan iktidardır. Bu bakımdan asli kurucu iktidarın, hukuk dışı ve sınırsız bir iktidar olduğu söylenebilir. ${ }^{121}$ Ortada bir devlet ve anayasal düzen yokken sıfırdan ve ilk elden hukuk dışı bir şekilde ve sınırsız olan iktidar, asli kurucu iktidar olarak adlandırılmaktadır. Kurucu iktidarın doktrin bakımından kökeni aslında Fransız düşüncesine dayanmaktadır. ${ }^{122} \mathrm{Bu}$ bakımdan milli egemenlik teorisinin fikir babası Sieyes ve halk egemenliği teorisinin fikir babası Rousseau, kurucu iktidar kavramı ve asli kurucu iktidar kavramı oluşumu üzerinde de oldukça etkili olmuşlardır. Asli kurucu iktidarın kimliği konusuna da bu açıdan bakmak, bu çalışmanın temel konusu olan egemenlik teorileri bağlamında değerlendirme yapmaya yardımcı olacaktır. Asli kurucu iktidarın kimliği, bu bakımdan iki ayrı şekilde değerlendirilebilir. İlk olarak asli kurucu iktidar, soyut bir kavram olan milletin kendisidir. Sieyes'in milli egemenlik teorisinden hareketle millet, asli kurucu iktidarın kendisidir ve anayasa onun eseridir. ${ }^{123}$ İkinci olarak asli kurucu iktidar, Rousseau'nun halk egemenliği teorisinden hareketle halktır yani halk1 oluşturan tek tek bireylerin toplamıdır. ${ }^{124}$ Sonuç olarak; demokratik bir toplumda anayasayı yapan asli kurucu iktidar ya millettir ya da halktır.

\footnotetext{
118 Kemal Gözler, Kurucu Iktidar (Ekin Kitabevi, 1998) 13.

119 ibid 10.

120 Teziç (n 60) 156; Gözler, Kurucu İktidar (n 117) 11.

121 Teziç (n 60) 156; "Buna karşın özellikle doğal hukuk savunucuları, asli kurucu iktidarın sınırlı olduğunu iddia etmektedir Yine bazı görüşler, asli kurucu iktidarın da hukuki olduğunu savunmaktadır. Fakat buradaki asıl ayrım hukuki pozitivizm ve doğal hukuk görüşlerindeki ayrımdan kaynaklanmaktadır.” Ayrıntılı bilgi için bkz. Gözler (n 117) 24.

122 Gözler (n 117) 18.

123 "İlk adım olarak bir anayasa yapılması gerektiğinden bahseden Sieyes, bu anayasayı kimin, nasıl yapabileceğini tartıșırken siyasal toplum, ulus ve ulusal iradeye ilişkin tanımlamalarda bulunmuştur. İlk olarak siyasal toplumu ele almıştır. Siyasal toplumun oluşmasında Sieyes'e göre üç evre vardır. İlk olarak birleşmek isteyen sayıca az ya da çok bağımsız bireyler mevcuttur. Bu durumda bile ulus oluşturmuşlardır, kullanmasalar da tüm haklara sahiplerdir. Bu dönem bireysel iradelerle ifade edilir, birleşmek onların eseridir ve iktidarın kaynağı onlardır.” Işık (n 39) 190.

124 Gözler, Kurucu İktidar (n 117) 86.
} 
İlk olarak milletin geçmişi ve geleceği kapsayan soyut bir varlık olduğundan hareketle asli kurucu iktidarın bu milleti temsil eden bir kurucu meclis tarafindan kullanılması gerekmektedir. ${ }^{125}$ Dolayısıyla anayasa, milli egemenlik teorisine göre kurucu meclis tarafından yapılmalıdır. Diğer taraftan halk egemenliği teorisinde ise anayasa, hukuki meşruiyetini doğrudan halktan almakta ve halkoylamasıyla (kurucu referandumla) oluşmaktadır. ${ }^{126}$

Kanaatimizce halk egemenliği teorisi, bugün yaşayan bireylerin toplamı olan bir halkın halkoylaması yaparak ileride yaşayacak bireylerden oluşan bir halkın egemenliğini sınırlandırmasını doğru bulmamalıdır. Buna karşılık milli egemenlik teorisi ise milletin bir karar alma anındaki bireylerin toplamından ayrı bir soyut kişiliği olduğu düşüncesine dayanmaktadır. Dolayısıyla buna göre milleti temsil eden bir meclis, soyut millet kişiliğini somut bireylerin toplamından bile korumak için yani çoğunluğun iktidarını sınırlandırmak için bir anayasa yapabilir. Pratik anayasalar ve yapım süreçleri incelendiğinde de mevcut anayasaların aslında o ülkedeki halk tarafindan tam anlamıyla desteklenmediği görülmektedir. Anayasalar, halkın çoğunluğunun kararı şeklinde tezahür edip popüler değerleri tanımlayan beyanlar işlevi gördügünde birey haklarını ve anayasal ilkeleri göz ardı edebilmektedir. ${ }^{127}$

Kuvvetler ayrıllı̆ı ilkesi ve halkın iradesini bölüp parçalayacak düşüncelerin varlığ 1 , halk egemenliği teorisiyle bağdaşmamaktadır. Halk egemenliği teorisi egemenliği bir bütün olarak görmektedir. Bu teoriye göre egemenlik bir bütün olarak halka aittir. ${ }^{128}$ Yine bu teoriyle çoğunluğun iradesini sınırlandıran anayasa mahkemesi gibi kurumların varlığı bağdaşmamaktadır. ${ }^{129}$ Buna karşılık anayasacılık, iktidarı sınırlandırmayı amaçlamaktadır. Ayrıca malumdur ki anayasal değerlerle halkın çoğunluğunun popüler istekleri genellikle bir çatışma içerisindedir. ${ }^{130}$ Halk egemenliği teorisi ise açıkça halkın isteklerini ön plana almaktadır. Halk egemenliği teorisine göre genel irade en üstündür. Genel iradenin yani halkın iradesinin üstünde başka hiçbir güç kabul edilemez. Peki nasıl oluyor da halk egemenliği teorisine dayanarak bir kurucu referandumla halk, kendi iradesini sınırlandıran bir anayasa

\footnotetext{
125 ibid 83

126 ibid 86; “Anayasaların demokratik usullerle yapım aşamalarına bakılacak olursa halkın katılmadığı bir şekilde hazırlanan anayasanın halkoyuna sunulması, halkın seçtiği bir meclisin hazırladığı anayasanın halkoyuna sunulması ve halkın seçtiği bir meclisin anayasayı hazırlayıp kendisinin kabul etmesi şeklinde üç usul karşımıza çıkmaktadır." Kaboğlu (n 3) 24; Dikkat edilecek olursa her ne kadar halk egemenliği teorisinin sonucu olarak anayasanın halkoyuyla kabul edilmesi usulü ortaya çıkmış olsa da bu usulün tam anlamıyla halk egemenliğinin uygulanması şeklinde işlemediği iddia edilebilir. Tabi ki bu usulde son söz halka tanınmaktadır. Halkın hazırlanmış olan anayasa tasarısını reddetme hakkı bulunmaktadır. Ancak bu usulde halkın doğrudan doğruda bir anayasayı yaptığını iddia etmek güç olacaktır. Zira doğrudan demokrasinin gerçek anlamda işletilerek tüm halkın aktif bir şekilde her maddeyi tartışması ve üzerinde istişare ederek anayasayı kabul etmesi mümkün görülmemektedir.

127 Mila Versteeg, 'Popüler Olmayan Anayasacılık' Şafak Evran Topuzkanamış (çev) (2018) 20 (1) Dokuz Eylül Üniversitesi Hukuk Fakültesi Dergisi 125, 126.

128 Gözler, Anayasa Genel Teori (n 18) 446.

129 ibid 447.

130 Versteeg, 'Popüler Olmayan Anayasacılık' (n 126) 128.
} 
yapmaktadır? ${ }^{131}$ Anayasacılık, kanun koyucu organı ya da halkın iradesini bile örneğin anayasada sayılan temel hak ve hürriyetlere dokunmama bakımından sınırlandırmayı amaçlamaktadır. Halk egemenliği teorisi, halkın genel iradesini sınırlandırmayı amaçlar ve bu amaç için yine halk referandumuyla bir anayasa yapar mı acaba? $\mathrm{Bu}$ bakımdan değerlendirildiğinde halk egemenliği teorisi, halk referandumunu öngörmüş olsa bile bu şekilde yapılan bir anayasayı en üstün saymaz diyebiliriz. Halk egemenliği teorisine göre anayasanın kanunlardan bir farkı olmamalıdır. Zira halk egemenliği teorisine göre halkın genel iradesi nasıl ki her zaman bir kanunu değiştirebiliyorsa ve halk egemenliği teorisi bunu halkın iradesinden başka denetleyebilecek bir üst organ veya yapıyı tanımıyorsa aynı şekilde anayasa için de benzer şeyleri düşünebiliriz. Halk egemenliği teorisine dayanan halk referandumuyla yapılan bir anayasa, gerçek anlamda anayasal bir devlet sunamayacaktır. Zira halk egemenliği teorisine göre en üstün olan anayasal değerler değil en üstün olan her zaman halkın iradesidir.

\section{Parlamento Çoğunluğunun ya da Halk Çoğunluğunun Sınırlandırılması Amacı Olarak Anayasacılık}

Anayasacılık, temel olarak iktidarın sınırlandırılması ve temel hak ve hürriyetlerin korunması amacıyla hiyerarşik olarak en üstün olan, zor değiştirilen, katı bir anayasanın yapılmasını isteyen bir anlayışa dayanmaktadır. ${ }^{132} \mathrm{Bu}$ bakımdan günümüz modern demokrasilerinde anayasalar, bir bakıma çoğunluk iradesini sınırlandıran belgelerdir. Buna karşın halk egemenliği anlayışının hâkim olduğu sosyalist devletlerde halk, işçi ve köylülerden oluşan emekçi sınıftır. ${ }^{133}$ Dolayısıyla işçi ve köylülerden oluşan emekçi sınıfın yani halkın iradesi, proletarya diktatörlüğünde vücut bulmalı ve bu çoğunluğun iradesi sınırlandırılamamalıdır. ${ }^{134}$

Anayasacılığa göre anayasanın üstünlüğü temel ilkedir ve kanun koyucu organ da çoğunluk iradesi de anayasayla sınırlandırılmalıdır. ${ }^{135}$ Anayasanın üstünlügüüü sağlayacak başlıca hukuki teknikler ise katı anayasa ve bir anayasa mahkemesi tarafından yapılan anayasallık denetimidir. ${ }^{136} \mathrm{Bu}$ teknikler, halk egemenliği

\footnotetext{
131 "Zaten popülist anayasaların azınlık haklarını korumada başarısı olduğu, evrenselci perspektiften uzak olduğu, sınırlı iktidarı sağlayamadığı görülmektedir.” ibid 196.

132 ibid 133.

133 Eren (n 24) 64.

134 Aslında Marksist düşüncenin kendi içinde tutarlı olması da bunu gerektirir. Anayasacılık mutlak anlamda doğru bir düşüncedir ön kabulü yanlıştır. Sosyalist bir devletin iktidarı sınırlandırmak gibi bir amacı olmamalıdır. Zira devletin sönümlenmesinden önceki evre olan ve özel mülkiyetin ortadan kaldırılması için gerekli olan devrim sonrası proletarya diktatörlüğünün, iktidarı sınırlandıracak bir anayasacılığa ihtiyacı yoktur. Burada zaten iktidar, emekçi halktır. Ve ayrı bir hukuk normunun üstünlüğünü tanımak zorunda değildir. Örneğin; Lenin'in siyasal düșüncesi, emekçi halkın iradesinin yansıması olan merkezi iktidarın tamamen sınırsız olması üzerine kuruludur. Lenin'in siyasal düşüncesi, hareket özgürlüğünü tehdit eden, iktidarı sınıllandırıcı ve kuvvetleri bölücü her türlü mekanizmaya karșıdır. 'Demokratik Merkeziyetçilik' adı verilen bu düşünce, azınlığın çoğunluğa bağımlı olması, ilkesine dayanmaktadır. George Sabine, Yakınçağ Siyasal Düşünceler Tarihi (Özer Ozankaya çev, Cem Yayınevi 2013) 323 vd.

135 Versteeg, 'Popüler Olmayan Anayasacılık' (n 126) 132.

136 Erdoğan (n 20) 26.
} 
teorisiyle bağdaşmamaktadır. Buna karşılık Schmitt, halk egemenliğine dayanan güçlü bir anayasacılık biçimi geliştirmeye çalışmıştır. ${ }^{137}$ Schmitt'in anayasal teorisi parlamentodaki çoğunluğun sınırlandırılmasını savunmaktadır. Ancak Schmitt, bu sınırlandırma yetkisini parlamentodaki çoğunluğa karşı güçlü bir halk çoğunluğuna dayanan popülist ve siyasal bir kuruma vermek istemektedir. Sonuç olarak aslında Schmitt, parlamentodaki çoğunluğun potansiyel tiranlığını basitçe Schmittyen ve popülist bir halk çoğunluğunun potansiyel tiranlığıyla değiştirmektedir. ${ }^{138}$ Dolayısıyla Schmitt' in halk egemenliği teorisine dayanan saf siyasal anlayışa ayrıcalık verme eğilimi, kendi anayasacılık düşüncesinin de altını oymaktadır. ${ }^{139}$

Anayasacılığa göre parlamentonun yapmış olduğu bir kanun anayasaya aykırı olamaz. Aynı şekilde anayasacılığa göre halk iradesinin yapmış olduğu bir kanun da anayasaya aykırı olamaz. Bu bakımdan anayasacılık, azınlıkları çoğunluk iradesinden korumayı ve halkın iradesini sınırlandırmayı amaçlamaktadır. Buna karşılık milli egemenlik teorisi, anayasacılığın öngördüğü anayasanın üstünlüğünü sağlayan anayasa mahkemesinin anayasallık denetimi gibi ilkelerle bağdaşmaktadır. ${ }^{140}$ Milli egemenlik teorisine göre egemenliğin kaynağını oluşturan millet, soyut bir kişilik olduğu için belli bir zaman dilimindeki hiçbir çoğunluk, tüm milletin çoğunluğu olamayacaktır. Aslında bir parlamentonun iradesi de tam anlamıyla milletin iradesini yansıtamaz. Anayasa yargısı ise geçmiş ve gelecek kuşakların iradesine aykırı belirli bir andaki çoğunluğun parlamento iradesini frenlemek suretiyle sınırlandırabilir. ${ }^{141}$ Dolayısıyla milli egemenlik teorisine göre belirli bir anda oluşmuş olan parlamentonun da belirli bir anda yaşayan halkın da iradesi egemenliğin asıl sahibi olan millet soyut kişiliği adına sınırlandırılmalıdır.

137 Lars Vinx, 'Carl Schmitt and the Problem of Constitutional Guardianship' in Matilda Arvidsson, Panu Minkkinen, Leila Brannström (edr), The Contemporary Relevance of Carl Schmitt: Law, Politics, Theology (Routledge 2015) $34 \mathrm{vd}<\mathrm{https}: / /$ www.repository.bilkent.edu.tr/handle/11693/50886> Erişim Tarihi: 15.01.2021.

138 "Sonuç olarak Schmitt, anayasal yargı ile sınırlanmamış çoğunluk arasında bir orta yol sunmakta başarısız olmuştur." ibid 35; Shmitt'in burada siyaseti ön plana çıkarması, Marksist düşünceyle ilgisi bakımından önem taşımaktadır. Zira Marksist hukuk teorisinde de "hukuk ve siyaset birbirinden ayrılamaz; hukuk siyasetin bir şeklidir." Oktay Uygun, Hukuk Teorileri (2. Bası, On İki Levha 2020) 166.

139 Vinx (n 136) 35; “Gao Quanxi ve Chen Duanhong gibi Çin'in önde gelen bazı anayasa teorisyenleri 'anayasacıllk' ruhunu içermeyen bir siyasal anayasa düşüncesi ortaya koymaktadır. Siyasal anayasacılık ya da politik anayasacılık (political constitutionalism) denilen bu düşünceye sahip düşünürler, Çin anayasasını anlama çabalarında Schmitt'ten ilham almışlardır. Ne var ki Gao, anayasanın normatif doğası gereği siyasi iktidarı sınırlama eğiliminde olduğunu söylemektedir. Dolayısıyla Gao, anayasayı her ne kadar siyasal olarak yorumlasa da sadece halkın siyasi kararının yansıması olarak tanımlanmaması gerektiğini belirtmektedir. Fakat yine de bu düşünceye göre anayasanın iktidarı sınırlandırmasından anlaşılan nihai nokta, partinin liderlik gücünü Ulusal Halk Kongresinin (National People’s Congress) halk egemenliğine nasıl tabi kılınacağıyla ilgilidir." Qi Zheng, 'Chinese Political Constitutionalism and Carl Schmitt' 2 vd <https://ssrn. com/abstract=3414042> Erişim Tarihi 16.01.2021; "Çin anayasası başta olmak üzere sosyalist anayasalarda daha çok Rousseaucu bir halk egemenliği düşüncesine dayanan ve anayasanın üstünlüğünden ziyade halk egemenliğinin (ve halkın iradesinin yansıması olan Ulusal Halk Kongresinin) üstünlüğünü kabul eden bir düşünce hâkimdir. Örneğin Çin'de halk egemenliğinin yansıması olan ve en üstün organ olarak görülen Ulusal Halk Kongresi, anayasayı yorumlamak ve anayasal denetim yapmakla yetkilidir. (Ulusal Halk Kongresinin Daimi Komitesi, Kongre adına bu görevi yerine getirmektedir.)" Zengyuan (n 96) 875; Aslında bu düşünceye göre egemenliğin kaynağı halktır. İktidar da halkın çoğunluğudur ve genel irade halkın çoğunluğunun iradesidir. Ulusal Halk Kongresini denetleyecek ayrı bir anayasal yargı organı olamaz. Proleter diktatörlük (ya da halk diktatörlüğü) anayasal yargı organı gibi organlarla sınırlandırılamaz.

140 Erdoğan (n 20) 25.

141 Gözler, Anayasa Genel Teori (n 18) 445. 


\section{Sonuc}

Anayasacılık, devlet iktidarını sinırlandırmayı ve bireylerin temel hak ve hürriyetlerini güvence altına almayı amaçlamaktadır. Bu bakımdan anayasacılık, hangi kişi, sınıf veya çoğunluğun elinde olursa olsun iktidarın keyfi olamayacağı ve sınırlı olacağıyla ilgilidir. Ancak bu sinırlılık, devletin kendi içinde olmalıdır. Anayasacılık, devletin egemenliğini zedeleyici olan ve dışarıdan bir müdahaleyle gelen sınırlandırmayı içermemektedir. Egemenliğin kaynağı ne kadar geniş bir tabana yayılırsa egemenliği kullanan iktidar da o kadar sınırlı olacaktır. Örneğin daha sonraları gelişen insan hakları düşüncesi ve bu düşünceye bağlı uluslararası insan hakları mahkemeleri, iktidarları önemli ölçüde sınırlandırmaktadır. Fakat bu düşünce, egemenliğin kaynağı olarak sayılamayacak, hatta devletlerin egemenliğini zedeleyecek bir düşüncedir. Oysa anayasacıllk, devletin en üstün güce sahip bir egemenliği olduğunu ve fakat egemenliği kullanan iktidarın devletin kendi isteğiyle sınırlandırılması gerektiğini yani otolimitasyonu ortaya koymaktadır. Bu bakımdan devletin kendi içinde kendi iktidarını sınırlandırması bakımından milli egemenlik teorisi ön plana çımaktadır.

Anayasal devlet, geçmişi ve geleceği kapsayan soyut bir millete dayanarak belirli bir andaki halkın çoğunluğunun iradesini de sınırlandırmaktadır. Anayasal devlet modeli, milli egemenlik teorisine dayanmakta ve soyut bir kavram olan milletten kaynaklı egemenlik düşüncesi sayesinde sınırlı bir iktidar sunmaktadır. Hem iktidarın kuvvetler ayrılığı sayesinde sınırlandırılmış olduğu hem de bireylerin temel hak ve hürriyetlerinin anayasal güvence altına alınıp denetleniyor olduğu bir anayasal devlet modeli, kanaatimizce milli egemenlik teorisi temelinde yükselmiştir. Buna karşıllık halk egemenliği teorisi, temel anayasal ilkelerin bile halkın çoğunluğunun iradesinden üstün olamayacağını savunmak durumundadır. Bu durumda da halkın çoğunluğunun demokratik iradesinin anayasal bir devlet modeli içinde sınırlandırılması kabul edilemeyecektir.

Tarihsel olarak ortaya çıkışları bakımından milli egemenlik teorisinin ve anayasacılığın burjuvaziyle sıkı ilişkisi bulunmaktadır. Eski kralın mutlak iktidarına karşı bir araç olarak kullanılan milli egemenlik, mutlak iktidarın halka geçmesinin önündeki en büyük engel olma görevini de ifa etmektedir. Bu açıdan bakıldığında bir tarafta monarşideki mutlak iktidar diğer tarafta da halkın mutlak iktidarı mevcuttur. Milli egemenlik teorisi ise soyut bir millete dayandırdığı egemenlik düşüncesiyle hem kralın mutlak iktidarını yıkmakta hem de halkın mutlak iktidara sahip olmasını engellemektedir. Kısacası milli egemenlik teorisi, her halükarda sınırlı bir iktidarı sağlamak amacına hizmet etmektedir.

Burjuva sınıfı, milli egemenlik teorisi ile aslında kendi sınıfının çıkarlarını gözetmiş ve anayasa yapım süreçleriyle kendi iktidarını kurumsallaştırma yoluna gitmiştir. 
Ancak zamanla kadınların ve mülkiyet sahibi olmayanların da oy verebilmesi gibi gelişmelerle milli egemenlik teorisi artık farklı bir anlama bürünmüş durumdadır. Günümüzdeki anlamları bakımından da milli egemenlik teorisi ile anayasacılık arasında hala sıkı bir ilişkinin var olduğu açıktır. Milli egemenlik teorisi, somut bireylerin toplamından çok daha geniş bir millet tanımı yaparak çoğunluğun iktidarını bile sinırlandırmayı uygun görmektedir.

Demokratik yönetimlerin hâkim olduğu günümüz dünyasında artık anayasacılık, çoğunluğun iktidarını sınırlandırmayı ve bireylerin temel hak ve hürriyetlerini çoğunluğa karşı korumayı amaçlayan bir akım olarak okunmalıdır. Artık günümüz demokratik toplumlarında anayasalar, azınlıklar lehine çoğunluk iktidarını sınırlandırmalı ve bireylerin temel haklarını çoğunluk iktidarına karşı güvence altına almalıdır. Bu bakımdan halk egemenliği teorisine dayanan çoğunluk iradesinin en üstün olduğu kanısının anayasacılıkla ve anayasal devlet modeliyle bağdaşması mümkün değildir. Buna karşılık çok daha geniş bir millet tanımı yapan milli egemenlik teorisinde, egemenliğin kaynağı geçmiş ve geleceği de kapsayan çok geniş bir tabana dayanmaktadır. Dolayısıyla milli egemenlik teorisine göre bir iktidar, çoğunluğa dayansa bile tüm millet adına keyfi karar alamamalıdır.

Hakem Değerlendirmesi: Dış bağımsız.

Çıkar Çatışması: Yazar çıkarlar çatışması bildirmemiştir.

Finansal Destek: Yazarlar bu çalışma için finansal destek almadığını beyan etmiştir.

Yazar Katkısı: Çalışma Konsepti/Tasarımı: S.N., F.Ç.; Veri Toplama: S.N., F.Ç.; Veri Analizi /Yorumlama: S.N., F.Ç.; Yazı Taslağı: F.Ç.; İçeriğin Eleştirel İncelemesi: S.N.; Son Onay ve Sorumluluk: S.N., F.Ç.

Peer-review: Externally peer-reviewed.

Conflict of Interest: The authors have no conflict of interest to declare.

Grant Support: The authors declared that this study has received no financial support.

Authors Contributions: Conception/Design of study: S.N., F.Ç.; Data Acquisition: S.N., F.Ç.; Data Analysis/Interpretation: S.N., F.Ç.; Drafting Manuscript: F.Ç.; Critical Revision of Manuscript: S.N.; Final Approval and Accountability: S.N., F.Ç. 


\section{Bibliyografya/Bibliography}

Akad M, Vural Dinçkol B ve Bulut N, Genel Kamu Hukuku (16. Bası, Der Yayınları 2020).

Aleinikoff TA, 'Sovereignty Studies in Constitutional Law: A Comment' (2000) 17 (2) Constitutional Commentary 197-203 < https://core.ac.uk/download/pdf/217203098.pdf> Erişim Tarihi 01.01.2021.

Anayurt Ö, Anayasa Hukuku Genel Kısım: Temel İlkeler, Kavram ve Kurumlar (3. Bas1, Seçkin Yayınevi 2019).

Andrew E, 'Jean Bodin on Sovereingty' (2011) 2 (2) Republics of Letters: A Journal for the Study of Knowledge, Politics and the Art 75-84<https://arcade.stanford.edu/sites/default/ files/article pdfs/roflv02i02_Andrew_060111_0.pdf> Erişim Tarihi 01.01.2021.

Aristotales, Politika (Mete Tunçay çev, 22. Bası, Remzi Kitabevi 2020).

Arslan R, Siyaset Bilimine Girişs (Dora Yayınevi 2016).

Atar Y, Türk Anayasa Hukuku (13. Bası, Seçkin Yayınları 2020).

Başgil AF, Esas Teşkilat Hukuku Cilt 1 (Baha Matbaası 1960).

Beard CA, An Economic Interpretation of the Constitution of the United States (Simon Schuster 1986).

Butzer KW, Early Hydraulic Civilization in Egypt: A Study in Cultural Ecology (Chicago Press 1976) < oi.uchicago.edu> Erişim Tarihi 01.01.2021.

Delice A, 'Bürokrasi: Monarşiden Cumhuriyete Değişmeyen İktidar' (2014) (17) Türkiye Adalet Akademisi Dergisi 41-61.

Dinçkol, B, 'Çoğunluk Tiranisine Karşı Bir Çözüm Yolu: Tocqueville’nin Siyasal Kuramı' (2004) 3 (5) Ístanbul Ticaret Üniversitesi Dergisi 149-163.

Doğan A, 'Hobbes’un Mutlak Egemenlik Hakkındaki İkilemi’ (2004) (35) Liberal Düşünce 117-126.

Ekiz S, 'Jean Bodin'in Siyaset Felsefesinde Devlet ve Egemenlik' (2020) 22 (2) Dokuz Eylül Üniversitesi Hukuk Fakültesi Dergisi 633-691.

Elster J, 'Forces and Mechanisms in the Constitution-Making Process' (1995) 45 (2) Duke Law Journal 364-396 < https://core.ac.uk/download/pdf/190850377.pdf> Erişim Tarihi 02.01.

Erdoğan M, Anayasal Demokrasi (13. Bası, Siyasal Kitabevi 2017).

Eren A, Anayasa Hukuku Dersleri: Genel Esaslar-Türk Anayasa Hukuku (2. Bası, Seçkin Yayınevi 2020).

Eroğlu H, 'Milli Egemenlik İlkesi ve Anayasalarımız' (1984) 1 (1) Atatürk Araştırma Merkezi Dergisi 137-163.

Eroğul C, Anatüzeye Giriş: “Anayasa Hukuku”na Giriş (7. Bası, İmaj Yayınc1lık 2004).

Eroğul C, Devlet Nedir? (İmge Kitabevi 1990).

Finn JE, Constitutions in Crisis: Political Violance and the Rule of Law (Oxford University Press 1991).

Friedrich CJ, Sinırlı Devlet (Mehmet Turhan çev, Gündoğan Yayınları 1999).

Gözler K, Anayasa Hukukuna Giriş (29. Bası, Ekin Yayınevi 2020).

Gözler K, Anayasa Hukukunun Genel Teorisi Cilt 1 (Ekin Yayınevi 2011).

Gözler K, Devletin Genel Teorisi (10. Bas1, Ekin Yayınevi 2020).

Gözler K, Kurucu İktidar (Ekin Kitabevi 1998).

Işık A, 'Sieyes Hala Yaşıyor mu?’ (2016) 22 (1) Marmara Üniversitesi Hukuk Fakültesi-Hukuk Araştırmaları Dergisi 183-199. 
İbni Haldun, Mukaddime Cilt I (Turan Dursun çev, Onur Yayınları 1977).

Jessop B, 'The State: Past, Present, Future' (2016) 7 Journal of Ritsumeikan Social Sciences and Humanities 73-86<http://www.ritsumei.ac.jp/acd/re/k-rsc/hss/book/pdf/ vol07_08.pdf > Erişim Tarihi 20.12.2020.

Kaboğlu İÖ, Anayasa Hukuku Dersleri: Genel Esaslar (15. Bas1, Legal Yayınevi 2020).

Kapani M, Kamu Hürriyetleri (7. Bas1, Yetkin Yayınlar1 1993).

Kapani M, Politika Bilimine Giriş (BB101 Yayınları 2019).

Keskin E, Anayasa Hukukunda Anayasacılık Düşüncesi: Gelişimi ve Temel Unsurları (Adalet Yayınevi 2020).

Kılıç Cepdibi A, 'İrade ve Egemenliğin Politik Alana Yansımasının Tiranik Sonuçları Üzerine Bir Değerlendirme' in Saim Üye, Nadire Özdemir, Zeynep İspir, Funda Kaya, Elif Çağla Yıldız (edr) Hukuk Felsefesi ve Sosyolojisi Arkivi: 28. Kitap (İstanbul Barosu Yayınları 2019).

Koçak M, Batı'da ve Türkiye'de Egemenlik Anlayışının Değişimi: Devlet ve Egemenlik: Eski Kavramlar-Yeni Anlamlar (Seçkin Yayınları 2006).

Korkut L, 'Ulus Devletin Ortaya Çıkışından Günümüze Kadar Kamu Hukukunda Egemenlik Kavramsallaştırmaları' (2015) 2 (1) İstanbul Medipol Üniversitesi Hukuk Fakültesi Dergisi 31-78.

Kubalı HN, Anayasa Hukuku Dersleri: Genel Esaslar ve Siyasi Rejimler (İstanbul Üniversitesi Hukuk Fakültesi Yayınları 1969).

Küçük A, 'Egemenlik (Hakimiyet), Halk Egemenliği ve Milli Egemenlik Tartışmaları ve Egemenlik Anlayışında Esaslı Dönüşüm' (2015) 0 (6) Uyuşmazlık Mahkemesi Dergisi 311-361.

Lakoff S, 'Liberty, Equality, Democracy: Tocqueville's Response to Rousseau' in George Feaver, Frederick Rosen (edr) Lives, Liberties and the Public Good: New Essays in Political Theory for Maurice Cranston (Palgrave Macmillan 1987).

Meriç C, Umrandan Uygarlığa (28. Bası, İletişim Yayınları 2015).

Meriç C, Saint-Simon: İlk Sosyolog, İlk Sosyalist (21. Bası, İletişim Yayınları 2019).

Morgan ES, Inventing the People: the Rise of Popular Sovereignty in England and America (W. W. Norton and Company 1989).

Nock AJ, 'Kriminal Bir Örgüt Olarak Devlet' Mustafa Erdoğan (çev) (2021) <https://www. sosyalbilimler.org/wp-content/uploads/2021/02/Albert-Jay-Nock-Kriminal-Bir-Orgut-OlarakDevlet.pdf> Erişim Tarihi 12.02.2021.

Norton A, 'Pentecost: Democratic Sovereignty in Carl Schmitt' (2011) 18 (3) Constellations 389$402<$ https://doi.org/10.1111/j.1467-8675.2011.00653.x> Erişim Tarihi 25.12.2020.

Oppenheimer F, Devlet (Alaeddin Şenel, Yavuz Sabuncu çevr, Phoneix Yayınevi 2005).

Ormanoğlu HD, 'Modern Devletin Bir Unsuru Olarak Egemenlik ve Uluslararası Ceza Mahkemesi' (2018) 9 (4) İпӧnӥ Üniversitesi Hukuk Fakültesi Dergisi 245-274.

Özbudun E, Anayasalcllık ve Demokrasi (2. Bas1, İstanbul Bilgi Üniversitesi Yayınlar1 2015).

Özçelik S, Anayasa Hukuku 1: Umumi Esaslar (Beta Yayınevi 1984).

Öztürk A, 'Egemenliğin Cumhuriyetçi Yapı Sökümü: Machiavelli, Rousseau ve Ulus Devlet' (2020) (58) Muhafazakâr Düşünce 85-106.

Paine T, İnsan Hakları (Mehmet Osman Dostel çev, İletişim Yayınları 2017).

Prokhovnik R, 'Internal/ External: The State of Sovereignty' (1996) 2 (3) Contermporary 7-20 $<$ https://doi.org/10.1080/13569779608454737> Erişim Tarihi 20.12.2020.

Sabine G, Yakınçağ Siyasal Düşünceler Tarihi (Özer Ozankaya çev, Cem Yayınevi 2013). 
Sancar M, 'Anayasal Demokrasi: Demokrasinin Sınırı mı, Güvencesi mi?’ in Ozan Ergül (ed) Demokrasi ve Yargl (Türkiye Barolar Birliği Yayınları 2005).

Sarıca M, 100 Soruda Siyasi Düşünce Tarihi (Milenyum Yayınları 2017).

Sarıca M, 100 Soruda Fransız İhtilali (Gerçek Yayınevi 1981).

Sartori G, 'Constitutionalism: A Preliminy Discussion' (1962) 56 (4) The American Political Science Review 853-864.

Saygılı A, 'Jean Bodin'in Egemenlik Anlayışı Çerçevesinde Kralın İki Bedeni Kuramına Kısa Bir Bakış’ (2014) 63 (1) Ankara Üniversitesi Hukuk Fakültesi Dergisi 185-198.

Schmitt C, Political Theology: Four Chapters on the Concept of Sovereignty (George Schwah çev, The University of Chicago Press 2005).

Shinoda H, 'Conflicting Notions of National and Constitutional Sovereignty in the Discourses of Political Theory and International Relations: A Genealogical Perspective' (Doktora Tezi, London School of Economics and Political Science 1998) <https://core.ac.uk/ download/pdf/46519243. pdf> Erişim Tarihi 20.12.2020.

Sieyes E, ‘Tiers Etat Nedir?’ Süheyp Derbil (çev) (1951) 8 (1) Ankara Üniversitesi Hukuk Fakültesi Dergisi, 126-207.

Şahin A, 'Siyasal Düşünceler Tarihinde 'Sınırlı Devlet' Fikrinin Kadimliği ya da Genel Kamu Hukuku Bağlamında İnsan, Özgürlük ve Devlet İktidarı Algısındaki Evrilme' (2011) 15 (3) Gazi Üniversitesi Hukuk Fakültesi Dergisi 311-362.

Şenel A, Siyasal Düşünceler Tarihi: Tarihöncesinde İlkçăgda Ortaçağda ve Yeniçağda Toplum ve Siyasal Düşünüş (7. Bası, Bilim ve Sanat Yayınları 2019).

Tanilli S, Dünyayı Değiştiren On Yıl: Fransız Devrimi Üstüne (Sayı Yayınları 1989).

Tarhan G, 'Rousseau ve Sieyes'de Egemenlik Kuramı' (2009) 2 (4) ETHOS: Felsefe ve Toplumsal Bilimlerde Diyaloglar 1-23.

Teziç E, Anayasa Hukuku (24. Bası, Beta Yayınevi 2020).

Tocqueville A, Çoğunluğun Zorbalı̆̆ (İnci Malak Uysal çev, Can Yayınları 2020).

Turhan M, 'Anayasacılık ve Kuvvetler Ayrılığı Kuramı' in Hayrettin Ökçesiz (ed) Hukuk Felsefesi ve Sosyolojisi Arkivi 2. Kitap (Afa Yayınc1lık 1995).

Uygun O, Devlet Teorisi (7. Bas1, On İki Levha 2020).

Uygun O, Hukuk Teorileri (2. Bası, On İki Levha 2020).

Versteeg M, 'Popüler Olmayan Anayasacılık' Şafak Evran Topuzkanamış (çev) (2018) 20 (1) Dokuz Eylül Üniversitesi Hukuk Fakültesi Dergisi 125-197.

Versteeg M ve Zackin E, 'American Constitutional Exceptionalism Revisited' (2014) 81 (4) University of Chicago Law Review 1641-1707 < https://www.jstor.org/stable/43151587> Erişim Tarihi 31.12.2020.

Vinx L, 'Carl Schmitt and the Problem of Constitutional Guardianship' in Matilda Arvidsson, Panu Minkkinen, Leila Brannström (edr), The Contemporary Relevance of Carl Schmitt: Law, Politics, Theology (Routledge 2015) 34-49 <https://www.repository.bilkent. edu.tr/handle/11693/50886> Erişim Tarihi 15.01.2021.

Yıldırım Y, 'Fransız Devrimi’nde Yurttaşlık ve Etkilerine Dair Bir Değerlendirme' (2019) 21 (Ek Say1) Trakya Üniversitesi Sosyal Bilimler Dergisi 251-271.

Yayla A, 'Anayasacılık, Anayasal Demokrasi ve İdeolojiler' (2012) (66) Liberal Düşünce 13-22.

Yayla A, Siyasî Düşünce Sözlüğü (2. Bası, Adres Yayınları 2003). 
Yücel B, 'Westphalia Anlaşmasından Nice Anlaşmasına: Egemenlik Kavramının Tarihsel Seyri ve Bir Prototip Olarak Avrupa Birliği’ (2006) 10 (1-2) Atatürk Üniversitesi Erzincan Hukuk Fakültesi Dergisi 165-202.

Zengyuan P, 'A Comparative Perspective on the United States and Chinese Constitutions' (1989) 30 (4) William and Mary Law Review 867-880 <https://scholarship.law.wm.edu/ cgi/viewcontent. cgi?article $=2021 \&$ context $=$ wmlr $>$ Erişim Tarihi 15.12.2020.

Zheng Q, 'Chinese Political Constitutionalism and Carl Schmitt' <https://ssrn.com/ abstract $=3414042>$ Erişim Tarihi 16.01.2021.

\section{Diğer Kaynaklar}

Amerika Hakkında: Amerika Birleşik Devletleri Anayasası, https://photos.state.gov/libraries/ turkey/231771/PDFs/abd-anayasasi.pdf Erişim tarihi 16.12.2020.

Britannica Dictionary, https://www.britannica.com/topic/constitutionalism Erişim tarihi 19.01.2021.

Constitution of United States of America, constituteproject.org/constitution/United_States_of_ America_1992 Erişim tarihi 15.12.2020.

Declaration of Human and Civic Rights, https:/www.conseil-constitutionnel.fr/sites /default/files/ as/root/bank_mm/anglais/cst2.pdf Erişim tarihi 29.12.2020.

Law Dictionary, www. dictionary.thelaw.com Erişim tarihi 10.11.2020.

TDK Sözlük, Erişim, www.sozluk.gov.tr Erişim tarihi 10.11.2020. 
